\title{
Áhrif meginreglna EES-réttar um bann við mismunun og takmörkun á fjórfrelsinu á sviði skattaréttar
}

\section{Ingibjörg Porsteinsdóttir}

Ágrip: Meginviðfangsefni greinarinnar er umfjöllun um áhrif meginreglunnar um bann við mismunun og takmörkun á grundvelli frelsisákvæða EES-samningsins á skattarétt einstakra ríkja. Lýst er peim takmörkunum á skattlagningarrétt ríkjanna sem leiða af reglunum og jafnframt hvaða lögmætu sjónarmið geta réttlætt undantekningar frá peim. Af niðurstöđu dómstóla má ráđa að ríkar kröfur eru gerðar til hlutleysis skattareglna gagnvart pjóðerni og staðsetningu aðila og byggir sú niðurstaða á markmiðum um hnökralausan innri markað. Hins vegar eru úrlausnir Evrópudómstólsins ekki alltaf skýrar pví mörg önnur sjónarmið hafa par áhrif, ekki síst viðleitni aðildarríkjanna til að halda forræði sínu á sviði skattaréttar auk pess sem erfitt getur verið að sampætta reglur Evrópuréttar og viðurkenndra reglna á sviði alpjóðlegs skattaréttar. Pá geta tvísköttunarsamningar og aðrir samningar á sviði skattaréttar einnig haft áhrif á niðurstöðu mála. EES-réttur byggir á sömu meginsjónarmiðum og gilda innan ESB par sem gert er ráð fyrir pví að sambærilegar reglur beggja samninga séu túlkaðar og peim beitt með sama hætti. Á hinn bóginn hafa hvorki afleidd löggjöf á sviði skattaréttar né breytingar á stofnsáttmála ESB, sem gerðar hafa verið eftir gildistöku EESsamningsins, verið teknar upp í samninginn. Petta getur leitt til pess að niðurstaða mála verður önnur gagnvart EES-ríkjum en gagnvart aðildarríkjum ESB.

Lykilorð: Evrópskur skattaréttur, meginreglur um bann við mismunun, fjórfrelsisákvæði EES og skattaréttur

\begin{abstract}
The main topic of this article is the impact of the principle of non-discrimination and restriction, based on the fundamental freedoms of the EEA Treaty, on member states' legislation on direct taxation. An important question is what circumstances can justify exceptions to this principle. Court decisions reflect a demand that taxation rules show considerable impartiality towards parties' nationality and location, a stance which is grounded in the goal of a smoothly functioning internal market. Yet the judgements of the EU Court are not always clear, and many other perspectives influence them, not least of all member states' efforts to keep control over tax law, as well as the difficulty of integrating European law with established rules in international tax law. Double taxation treaties and other tax law agreements can also influence the way such affairs are resolved. EEA law is founded on the same main perspectives that are followed in the EU and the expectation is that similar provisions of the two agreements will be interpreted and applied in the same way. However, neither the EU's secondary legislation in the tax law area nor those changes in the EU treaties which have been made since the EEA Treaty went into force have been implemented in the EEA agreement. This can mean that decisions in cases involving EEA countries can differ from those involving only EU countries.
\end{abstract}


Keywords: European tax law, principle of non-discrimination and restriction, fundamental freedoms of the EEA and tax law

\section{Inngangur og afmörkun efnis}

EES-samningurinn fjallar ekki með beinum hætti um skattlagningu og afleidd löggjöf Evrópusambandsins sem varðar beina skatta var hvorki tekin upp í innlenda löggjöf við upphaflega gerð samningsins né síðar. Engu að síður er nú ljóst að almennar reglur samningsins, einkum ákvæðin um fjórfrelsið og almenn regla um almennt bann við mismunun á grundvelli pjóðernis, takmarka heimild stjórnvalda til að haga skattamálum sínum að vild. Pannig hefur dómstóll Evrópusambandsins og EFTAdómstóllinn komist að peirri niðurstöðu í fjölmörgum málum að skattalöggjöf aðildarríkjanna hafi falið í sér brot á pessum reglum með pví að mismuna borgurum aðildarríkja sambandsins eða EES-svæðisins, ýmist með beinum eða óbeinum hætti eða með pví að takmarka eða hindra borgara svæðisins í að fá notið frelsisákvæða samninganna.

Í pessari grein verður gerð grein fyrir peim meginsjónarmiðum sem beitt er við mat á pví hvort skattareglur aðildarríkja Evrópusambandsins eða EES-ríkja samræmast samningsskuldbindingum peirra.

Uppbygging greinarinnar er með peim hætti að fyrst er gerð grein fyrir tengslum EES-réttar og skattaréttar og farið nokkrum orðum um próun skattaréttar innan Evrópusambandsins auk pess sem tengslum réttarreglna á vettvangi Evrópusambandsins og Evrópska efnahagssvæðisins eru gerð skil. Pá er fjallað um hvaða frelsi EES-samningnum er ætlað að vernda og hvernig skattareglur geta takmarkað petta frelsi með ólögmætum hætti, annaðhvort með beinni eða óbeinni mismunun á grundvelli pjóðernis eða með annars konar takmörkunum á fjórfrelsisákvæðum samningsins. Að síðustu er gerð grein fyrir sjónarmiðum sem lúta að brýnum almannahagsmunum, sem réttlætt geta annars ólögmætar ráđstafanir aðildarríkjanna og reifuð sjónarmið sem skattyfirvöld hafa látið reyna á í dómsmálum í pví efni. Sjónum er fyrst og fremst beint að dómum sem varða skattlagningu fyrirtækja en í meginatriðum eiga sömu reglur við um skattlagningu einstaklinga. Dómar Evrópudómstólsins eru aðalviðfangsefni greinarinnar par sem dómar EFTA-dómstólsins eru fáir á pessu sviði.

\section{Tengsl EES-réttar og skattaréttar}

Skattareglur eru í eðli sínu landsreglur par sem heimildir einstakra ríkja til að heimta skatt byggjast annaðhvort á tengslum skattgreiðanda við landið eða tengslum peirra verðmæta eða tekna, sem skattleggja á, við landið. Vísað er til pessara tengsla annars 
vegar sem alheimsskattareglunnar og hins vegar sem upprunareglunnar. ${ }^{1}$ Skattskylda á Íslandi byggist á báðum pessum reglum, svo sem algengt er. Annars vegar hvílir full skattskylda á peim sem eru heimilisfastir á Íslandi og felst í pví að skattskyldan nær til allra tekna viðkomandi, hvar sem peirra er aflað. Petta er meginregla tekjuskattslaganna og kemur fram í 1. og 2. gr. laga 90/2003. Heimilisfesti ræður hér skattskyldunni. Hvað einstaklinga varðar pá teljast peir heimilisfastir sem eiga hér lögheimili. ${ }^{2}$ Fyrirtæki eru heimilisföst hér á landi ef pau eru skráð hér á landi, telja heimili sitt hér á landi samkvæmt sampykktum sínum eða ef raunveruleg framkvæmdastjórn pess er hér á landi. Skattskylda pessara aðila hvílir á alheimstekjureglunni. Út frá skattapólitísku sjónarmiði er pessari reglu ætlað að ná fram ákveðnu jafnræði meðal skattgreiðenda par sem geta manna til að greiða skatta fer eftir heildartekjum peirra en ekki eftir pví hvar teknanna er aflað. Hins vegar geta aðrir, p.e. peir sem ekki hafa hér fasta búsetu, borið takmarkaða skattskyldu hér á landi á grundvelli upprunareglunnar. Í pví felst að skattskyldan á Íslandi nær eingöngu til peirra tekna sem aflað er hér á landi. Skattskyldan byggir í pessu tilviki á tengslum tekna við landið fremur en tengslum skattgreiðandans við pað. ${ }^{3}$

Reglurnar í kringum fulla og takmarkaða skattskyldu eru í mörgu frábrugðnar, bæði hvað varðar útreikning skattstofns og skatthlutfall. Af pessari uppbyggingu skattkerfisins leiðir pví að í fjölmörgum tilvikum getur verið um mismunandi skattlagningu að ræða sem byggir á búsetu eða staðsetningu skattgreiðanda. •að er rannsóknarefni hverju sinni hvort sú mismunun brjóti í bága við alpjóðlega samninga sem Ísland er aðili að. Próun undanfarinna ára er augljóslega sú að skattareglur teljast, í víðtækara mæli en áður, brjóta í bága við ákvæði alpjóðasamninga sem leggja bann við mismunun og kveða á um skyldu ríkja til að gæta jafnræðis. Ekki síst gætir pessarar próunar á sviði Evrópuréttar, p.e. réttar Evrópusambandsins og EES-réttar, svo sem nánar er fjallað um í pessari grein. Ađrir alpjóðasamningar hafa líka haft áhrif í pessa átt. Í tvísköttunarsamningum er bann við mismunun sem reynt hefur á í ríkari mæli en áður og skattareglur hafa einnig komið til skoðunar í tengslum við brot á ákvæðum Mannréttindasáttmála Evrópu. ${ }^{4}$

Annað einkenni skattareglna, sem leiðir af lögsögu og fullveldi ríkis, er pað að hverju ríki er heimilt að haga skattamálum að vild. Flest ríki hafa verið treg til að semja frá sér petta frjálsræði. •að liggur í augum uppi að miklir hagsmunir felast í pví fyrir sérhvert ríki að hafa sem mest frjálsræði í skattamálum. Skattkerfið er grundvöllur tekjuöflunar ríkisins og hefur úrslitaáhrif á möguleika pess til að ákveða

1 Á dönsku nefnt „globalintektstprinsippet“ og „territorialprinsippet“ en á ensku „residence jurisdiction“ og „source jurisdiction.“ Sjá nánar almenna umfjöllun um lögsögu skattaréttar í Brian J. Arnold og Michael J. McIntyre, International Tax Primer, bls. 15-24.

2 Fleiri aðilar en peir sem eiga hér lögheimili geta borið fulla skattskyldu á grundvelli 1. gr., s.s. peir sem dvelja eða starfa hér lengur en 183 daga á sérhverju 12 mánaða tímabili, sbr. 2.-4. tölul. 1. gr.

3 Um skattapólitísk sjónarmið í alpjóðlegum skattarétti sjá nánar Frederik Zimmer, Internasjonal inntektskatterett, bls. 69-72.

4 Sjá m.a. Philip Baker, „Taxation and the European Convention on Human Rights, “ bls. 211-377. 
umfang útgjalda og um leið umfang samneyslu í pjóðfélaginu og pjónustu hins opinbera. Pannig hefur verið almenn tregða hjá aðildarríkjum Evrópusambandsins að samræma skattareglur aðildarríkjanna pótt framkvæmdastjórnin hafi beitt prýstingi í pá átt. Við gerð EES-samningsins var skattamálum, p.e. beinum sköttum, alfarið haldið utan samningsins og svo virðist sem peim hafi verið lítill gaumur gefinn við samningsgerðina. ${ }^{5}$ Раð hefur hins vegar orðið æ ljósara að almenn ákvæði samningsins setja pví talsverðar skorður með hvaða hætti EES-ríkin geta hagað skattamálum sínum. Reynir par helst á ákvæði 31. gr. samningsins um staðfesturétt, 40. gr. um frjálsa fjármagnsflutninga og 28. gr. um frjálsa för launafólks, að pví er skattlagningu einstaklinga varðar, auk hins almenna ákvæðis um bann við mismunun á grundvelli pjóðernis í 4. gr. samningsins.

\subsection{Reglur Evrópusambandsins um beina skatta}

Í meginmáli sáttmálans um Evrópusambandið (ESB) ${ }^{6}$ eru afar fá ákvæði sem varða beina skatta enda eru skattlagningaheimildir á valdsviði aðildarríkjanna. Hins vegar eru nokkur ákvæði sem fjalla um vöruskatta og aðra óbeina skatta. ${ }^{7}$

Til að tilskipun á sviði beinna skatta öðlist gildi innan ESB parf einróma sampykki allra aðildarríkjanna en almenna reglan um tilskipanir er varða innri markaðinn er hins vegar sú að aukinn meirihluti nægir til sampykkis peirra. ${ }^{8}$ Krafan um einróma sampykki tilskipana á sviði skattamála hefur gert pað mjög pungt í vöfum að fá slíkar tilskipanir sampykktar og tillögur par að lútandi eru árum saman til meðferðar innan stofnana Evrópusambandsins. Niðurstaðan er pví oft reglur sem eru órafjarri upphaflegum tillögum, byggðar á málamiðlunum milli margra og ólíkra hagsmuna og sjónarmiða. Pær tilskipanir sem settar hafa verið á pessu sviði eru tilskipun

5 Sjaldnast er minnst á beina skatta í gögnum eða ritum frá peim tíma er samningurinn var í undirbúningi eða öðlaðist gildi. Í Thérése Blanchet o.fl., The Agreement on the European Economic Area, bls. 20 er pess eins getið um skattamál að pau eru í dæmaskyni nefnd sem málefni sem gætu á síðari stigum orðið hluti EES-samningsins á grundvelli 118. gr., ef samningsaðilar óskuðu eftir pví.

6 Hér er átt við sáttmálann um starfsemi Evrópusambandsins (e. Treaty on the Functioning of the European Union), eins og hann er nefndur eftir sampykkt Lissabon sáttmálans sem gekk í gildi 1. desember 2009. Sú útgáfa sem vísað er til í pessari grein er uppfærð útgáfa sem birt er í OJ 30.3.2010 (OJ C 85 E/47). Með sáttmálanum hafa verið felldar út allar tilvísanir til Evrópubandalagsins (EB) og pví er hér notast við Evrópusambandið og vísað til greina sáttmálans með ESB fyrir aftan númer greina (e. TFEU). Notast er við hugtökin Evrópusambandsréttur eða sambandsréttur par sem áður var vísað til EB-réttar eða bandalagsréttar. Pegar vísað er til greina í eldri útgáfu sáttmálans er notuð skammstöfunin EB fyrir aftan númer greina. Er pá átt við greinanúmer eins og pau voru fyrir gildistöku Lissabon sáttmálans.

7 Ákvæði 65. gr. ESB (áður 58. gr. EB) er eina ákvæðið sem víkur að beinum sköttum og veitir aðildarríkjum heimild til að grípa til aðgerða gegn skattalagabrotum. Ákvæði petta kom fyrst inn með Maastricht sáttmálanum, grein G (15). Samsvarandi ákvæði er ekki í EES-samningnum. Pá var í EB-samningnum ákvæði í 293. gr. EB um tvísköttunarsamninga milli aðildarríkja ESB en ákvæðið var fellt brott með Lissabon sáttmálanum.

8 Reglur sem varða beina skatta eru settar með heimild í 115. gr. ESB (áður 94. gr. EB) en flestar aðrar tilskipanir sem varða innri markaðinn eru settar á grundvelli 294. gr. ESB (áður 251. gr. EB). 
94/435/EC varðandi skattlagningu móður- og dótturfélaga, tilskipun 90/434/EC um samruna o.fl., tilskipun 2003/49/EC um skattlagningu vaxta og póknana og tilskipun 2003/48/EC um skattlagningu vaxta af sparifé einstaklinga. Að auki eru í gildi samningur á milli Evrópusambandsríkjanna um gerðardóm í málum er varða milliverðlagningu (transfer pricing), sbr. tilskipun 90/436/EEC og samningur um gagnkvæm skipti á upplýsingum í skattamálum, sbr. tilskipun 77/799/EEC, sem breytt hefur verið nokkrum sinnum síðan, síðast með tilskipun 2004/56/EC. Framkvæmdastjórnin hefur lengi verið peirrar skoðunar að fella eigi niður kröfuna um einróma sampykki aðildarríkja að pví leyti sem skattamál varða starfrækslu innri markaðarins. Hún hefur bent á að pað sé nánast útilokað að ná fram nauðsynlegri samræmingu skattareglna ríkja ESB með núverandi fyrirkomulagi. ${ }^{9}$ Um árabil hefur einnig verið unnið að pví á vettvangi framkvæmdastjórnarinnar að móta reglur um tiltekna samræmingu á skattareglum Evrópusambandsins án pess að ápreifanlegur árangur hafi náðst í peim efnum. ${ }^{10}$

Pað eru hins vegar almenn ákvæði sáttmálans sem hafa með beinum hætti haft áhrif á skattalöggjöf aðildarríkja sambandsins. Petta eru fyrst og fremst ákvæði um fjórfrelsið, p.e. um frjáls vöru- og pjónustuviðskipti, frjálsa för fólks, par á meðal frelsi til að hefja og stunda sjálfstæða atvinnustarfsemi og frelsi til fjármagnsflutninga í 45.-66. gr. sáttmálans. Hvað varðar skatt á fyrirtæki pá hefur einkum reynt á ákvæðin um rétt fólks til að setja á stofn félög og fyrirtæki, (staðfesturétturinn) í 49. og 54. gr. ESB (áður 43. og 48. gr. EB), og ákvæði um frjálsa fjármagnsflutninga í 63. gr. ESB (áður 56. gr. EB). Nátengt fjórfrelsisreglunum er svo almennt bann við mismunun á grundvelli ríkisfangs eða pjóðernis í 18. gr. ESB (áður 12. gr. EB). Auk pessa hefur reynt á lögmæti skattareglna út frá banni við ríkisstyrkjum í 107. og 108. gr. ESB (áður 87. og 88. gr. EB).

Í upphafi komu engin mál varðandi beina skatta til kasta Evrópudómstólsins en frá pví í upphafi tíunda áratugar síðustu aldar hefur fjöldi mála vaxið hröðum skrefum. ${ }^{11}$ Fyrsta mál dómstólsins á sviði skattamála var Avoir-Fiscal málið frá 28. janúar $1986^{12}$ par sem útibú félaga, sem skráð voru erlendis, nutu ekki sömu skattaívilnana og frönsk fyrirtæki pótt pau að öðru leyti væru skattlögð með sama hætti. Pessa mismunun taldi dómstóllinn brjóta gegn págildandi 52. gr. EB um staðfesturétt fyrirtækja (nú 49. gr. ESB).

49. grein ESB og 31. gr. EES-samningsins, sem eru efnislega samhljóða, er ætlað að tryggja að ríkisborgarar aðildarríkja Evrópusambandsins og Evrópska efnahagssvæðisins geti án nokkurra hindrana sett á stofn fyrirtæki eða rekið sjálfstæða at-

$9 \operatorname{COM}(2003) 548$ final, bls. 7.

10 Sjá umfjöllun um pær tilraunir í Ingibjörg Porsteinsdóttir, „Evrópskur skattaréttur: átök og árangur á sviði skattaréttar Evrópusambandsins."

11 Fram til ársins 1985 var enginn úrskurður kveðinn upp um beina skatta, á tímabilinu 1986-1994 voru 5 mál á pessu sviði og á árunum 1995-2005 voru pau tæplega 50. Í árslok 2006 voru um 50 mál á sviði beinna skatta í gangi fyrir dómstólnum.

12 Mál C-270/83. 
vinnustarfsemi í öðrum ríkjum innan svæðisins. Peir eiga með öðrum orðum að vera eins settir gagnvart lögum og stjórnvöldum viðkomandi ríkis og pess eigin ríkisborgarar. Í staðfesturéttinum felst einnig réttur fyrirtækja til að setja á stofn önnur fyrirtæki utan síns heimalands og að hafa val um rekstrarform peirra, hvort pau vilji reka pau sem dótturfélög eða útibú. Markmið pessara reglna eru fyrst og fremst pau að veita ríkisborgurum aðildarríkja svæðisins tækifæri til að taka pátt í og njóta arðs af efnahagslífi utan síns heimalands á traustum og viðvarandi grundvelli, eins og segir í 53. grein Cadbury Schweppes málsins, C-196/04.

\subsection{Samspilið milli réttar ESB og EES}

Eitt meginmarkmið EES-samningsins er að búa til einsleitt efnahagssvæði. Með einsleitni er átt við að eins reglur og samræmd framkvæmd gildi á öllu svæðinu á peim sviðum sem samningurinn nær til. Í aðfaraorðum samningsins segir m.a. að pað sé markmið samningsaðila að mynda öflugt og einsleitt evrópskt efnahagssvæði er grundvallist á sameiginlegum reglum og sömu samkeppnisskilyrðum, tryggri framkvæmd, meðal annars fyrir dómstólum, og jafnrétti, gagnkvæmni og heildarjafnvægi hagsbóta, réttinda og skyldna samningsaðila. Jafnframt segir að samningsaðilar hafi einsett sér að beita sér fyrir pví að frelsi til vöruflutninga, fólksflutninga, pjónustustarfsemi og fjármagnsflutninga verði sem víðtækast á öllu svæðinu.

Ákvæði EES-samningsins, sem helst reynir á varðandi beina skatta, p.e. ákvæðin um frjálsa för launafólks í 28. gr., staðfesturéttinn í 31.-35. gr. og frjálsa fjármagnsflutninga í 40. gr. og hið almenna ákvæði um bann við mismunun á grundvelli ríkisfangs í 4. gr., eru efnislega sambærileg ákvæðum um sama efni í ESB sáttmálanum pótt sá síðarnefndi hafi tekið ýmsum breytingum frá gildistöku EES-samningsins. ${ }^{13}$ Pó hafa einstakar breytingar verið gerðar á sáttmálum Evrópusambandsins sem snúa beint að skattamálum, s.s. 65 gr. ESB sem fela í sér ákveðnar tilslakanir á skattareglum sem tengjast frjálsum fjármagnsflutningum. ${ }^{14}$

Pá er pess líka að gæta að tilskipanir ESB á sviði beinna skatta hafa ekki verið teknar upp í EES-samninginn og hafa pví ekki áhrif í EES-ríkjunum. Jafnframt verður að hafa í huga að tvíhliða eða marghliða samningar einstakra ríkja, einkum tvískött-

13 Sjá nánar samanburð Stefáns Más Stefánssonar í Evrópusambandið og Evrópska efnahagssvæðið á efnislegu innihaldi ESB og EES reglna.

14 Grein pessi kom fyrst inn í sáttmála EB með Maastricht sáttmálanum árið 1993 og var pá grein 73d. Í greininni segir að m.a. að ákvæði sáttmálans um frjálsa fjármagnsflutninga komi ekki í veg fyrir að í skattalöggööf aðildarríkjanna sé gerður greinarmunur á skattgreiðendum sem ekki eru í sömu stöðu að pví er varðar annaðhvort búsetustað eða hvar fjárfest er. Jafnframt er ákvæði í greininni sem heimilar aðildarríkjum að grípa til nauðsynlegra aðgerða til að koma í veg fyrir skattalagabrot. Gildissvið greinarinnar var af ýmsum talið óljóst og jafnvel ekki talið fela í sér annað en staðfestingu á fyrri dómaframkvæmd Evrópudómstólsins. Sjá m.a. Kristina Ståhl, „EU-samarbetets betydelse på den direkta beskattningens område - gemenskapens kontra medlemsstaternas intressen." Með Lissabon sáttmálanum var bætt við ákvæði i 4. mgr. greinarinnar sem varðar aðgerðir gagnvart priðju ríkjum. 
unarsamningar, geta haft áhrif á niðurstöðu mála á sviði Evrópuréttar. Framangreind atriði kunna í einhverjum tilvikum að leiða til pess að ekki er unnt að túlka reglur EES-samningsins á sama hátt og reglur ESB á sama sviði og torvelda pannig að markmiðum um einsleitni verði náð. Að minnsta kosti í einu máli hefur Evrópudómstóllinn komist að peirri niðurstöðu að mismunandi reglur giltu annars vegar innan ESB og hins vegar gagnvart EES-ríkjunum á peirri forsendu að í gildi væri samningur milli aðildarríkja ESB um gagnkvæma aðstoð í skattamálum. ${ }^{15}$ Petta verður að hafa í huga við mat á gildi dóma Evrópudómstólsins. Réttarpróun næstu ára mun leiða í ljós hvort misræmi verður meira eða minna einkennandi á sviði skattaréttar.

Við núverandi stöðu EES-réttar og ESB-réttar má hins vegar ganga út frá pví að í skattamálum reyni helst á meginreglur ESB/EES réttar um fjórfrelsið, sem eru í öllum aðalatriðum eins á öllu EES svæðinu, og pví hægt að ganga út frá pví að markmið um einsleitni sé í flestum tilvikum hægt að leggja til grundvallar úrlausn mála. Til að ná fram pví markmiði hér á landi er bæði beitt almennum lögskýringaraðferðum varðandi pjóðréttarsamninga og sérstökum aðferðum við lögskýringar og meðferð réttarheimilda sem eiga sér ekki hliðstæðu í öðrum pjóðréttarsamningum.

Í fyrsta lagi skal skýra lög og reglur til samræmis við ákvæði EES-samningsins. Petta kemur fram í 3. gr. laganna um Evrópska efnahagssvæðið og er í samræmi við almennt viðurkennda lögskýringarreglu varðandi pjóðréttarsamninga. Í henni felst að reynt er að skýra innlendar lagareglur til samræmis við ákvæði pjóðréttarsamninga eftir pví sem framast er kostur. Af dómafordæmum Hæstaréttar má ráđa að rétturinn gengur langt í að beita slíkri samræmisskýringu. ${ }^{16}$

Í öðru lagi hefur EES-samningurinn ásamt bókunum og viðaukum við hann verið lögfestur í heild, sbr. lög nr. 2/1993, með síðari breytingum. Pví parf ekki að velkjast í vafa um gildi peirra reglna sem skýrt koma fram í samningnum sjálfum, svo sem vera kynni ef samningurinn væri ólögfest pjóðréttarskuldbinding. Ákvæði samningsins hafa pví að pessu leyti sömu stöđu sem réttarheimild og önnur sett lög, sem hefur m.a. pá pýðingu að einstaklingar geta byggt rétt sinn á ákvæðum samningsins. Ákvæði EES-samningsins kunna hins vegar að ganga framar ákvæðum annarra laga sé petta tvennt ósamrýmanlegt. Petta er talið byggja á 3. gr. laganna pótt orðalag ákvæðisins gefi ekki skýra vísbendingu í pessa átt. Í 3. gr. laganna segir einfaldlega að skýra skuli lög og reglur, að svo miklu leyti sem við á, til samræmis við EES-samninginn og pær reglur sem á honum byggja. Í athugasemdum við greinina í frumvarpi laganna segir hins vegar: „Í 3. gr. felst m.a. að innlend lög sem eiga stoð í EES-samningnum verði jafnan túlkuð sem sérreglur laga gagnvart ósamræmanlegum yngri lögum, að pví leyti að yngri lög víki peim ekki ef pau stangast á, nema löggjafinn taki pað sérstaklega fram. ${ }^{\text {“17 }}$ Segir par ennfremur að pessi regla sé nauðsynleg

15 Sjá C-540/07, Framkvæmdastjórnin gegn Ítalíu. Um dóm pennan er nánar fjallað í kafla 3.3. um virkt skatteftirlit.

16 Sjá t.d. hrd. 1990.2.

17 Alpingistíðindi, 116. löggjafarping (1992), mál 1, pingskjal 1. 
til að tryggja samræmi í reglunum á Evrópska efnahagssvæðinu. Í hrd. 2003.2045 beitir Hæstiréttur pessari lögskýringu og kemst að peirri niðurstöðu að ákvæði 2. mgr. 14. gr. EES-samningsins sé sérregla sem gangi framar ákvæði 6. tölul. 14. gr. laga nr. 50/1988 um virðisaukaskatt. Talið var að túlka bæri ákvæði EES-samningsins sem sérreglu fram yfir ákvæði virðisaukaskattslaga og peim síðarnefndu yrði pví ekki beitt. Pessi niðurstaða er hins vegar ekki augljós með skoðun á innihaldi og og eðli peirra laga sem um ræðir. Pvert á móti sýnist eðlilegt að líta á lögin nr. 50/1988 sem sérlög gagnvart almennum ákvæðum EES-samningsins í lögum nr. 2/1993.

Í priðja lagi hafa dómsúrlausnir Evrópudómstólsins mikla pýðingu við túlkun EES-samningsins. Samkvæmt 6. gr. samningsins ber við framkvæmd og beitingu ákvæða hans að túlka pau í samræmi við úrskurði dómstóls Evrópubandalaganna ${ }^{18}$ sem máli skipta og kveðnir hafa verið upp fyrir undirritunardag samningsins að pví tilskildu að ákvæði EES-samningsins séu efnislega samhljóða ákvæðum í sáttmálum bandalaganna. Samsvarandi ákvæði er einnig í 1. mgr. 3. gr. samnings EFTA-ríkjanna um stofnun eftirlitsstofnunar og dómstóls (ESE). Í 2. mgr. 3. gr. ESE er ennfremur ákvæði sem varðar úrlausnir Evrópudómstólsins sem falla eftir gildistöku EES-samningsins. Par segir að taka skuli tilhlýðilegt tillit til peirra meginreglna sem mælt er fyrir um í viðkomandi úrskurðum dómstólsins. Með pessu móti hafa úrlausnir Evrópudómstólsins verið gerðar að mikilvægum fordæmum og lögskýringargögnum. Íslenskum stjórnvöldum og dómstólum ber að taka mið af peim sem og stofnunum á borð við ESA og framkvæmdastjórn ESB sem og EFTA-dómstólinn. Varðandi dóma, sem fallið hafa fyrir gildistökudag EES-samningsins, segir að pað séu peir dómar sem „máli skipta“ sem leggja beri til grundvallar. Með pví er átt við dóma sem varða pau svið sem EES-samningurinn tekur til, einkum fjórfrelsisreglurnar og reglur um samkeppni. Auk pess kann dómstóllinn að móta meginreglur í dómum sem strangt til tekið varða önnur svið en ber samt að líta á sem meginreglur í ESB-rétti, m.a. við framkvæmd og beitingu reglna á framangreindum sviðum. Telja má víst að pær meginreglur, sem Evrópudómstóllinn hefur pannig mótað á sviðum sem EES-samningurinn tekur strangt til tekið ekki til en teljast engu að síður til meginreglna í ESBrétti, geti einnig talist hluti EES-samningsins á grundvelli 6. gr. hans. ${ }^{19}$ Prátt fyrir orðalag 2. mgr. 3. gr. ESE, varðandi gildi dóma sem fallið hafa eftir gildistökudag EES-samningsins, er á pví byggt að í reynd hafi aðgreining á dómum fyrir og eftir pað tímamark litla eða enga pýðingu í framkvæmd. ${ }^{20}$ Pessi staða úrlausna Evrópudómstólsins er mikilvægur lykill að pví að tryggja einsleitni á EES-svæðinu pví dómstóllinn hefur með áratuga langri starfsemi haft víðtæk áhrif á innhald peirra meginreglna sem settar eru fram í ESB-sáttmálanum og eiga sér samsvörun í EES-samn-

18 Heiti dómstólsins breyttist með Lissabon-sáttmálanum og heitir nú á ensku Court of Justice í stað Court of Justice of the European Communities. Hér vísast til hans sem Evrópudómstólsins eða dómstóls Evrópusambandsins.

19 Davíð Pór Björgvinsson, EES-réttur og landsréttur, bls. 311.

20 Davíð Pór Björgvinsson, EES-réttur og landsréttur, bls. 316. 
ingnum. Ef svigrúm væri til mismunandi túlkunar ákvæðanna væri markmið um einsleitni fyrir bí. Á grundvelli pess sem að framan er rakið er pví gengið út frá pví að allar úrlausnir Evrópudómstólsins, sem varða beina skattlagningu aðildarríkja ESB og sampýðanleika peirra við fjórfrelsisákvæði EB-samningsins, skuli lagðar til grundvallar í sambærilegum málum hér á landi.

Í fjórða og síðasta lagi skal nefnt hér að liður í pví að tryggja einsleitni reglna á Evrópska efnahagssvæðinu er möguleiki íslenskra dómstóla til að leita álits EFTAdómstólsins varðandi álitaefni honum tengd. EFTA-dómstóllinn, sem er í flestu hliðstæður dómstól Evrópusambandsins, notar svo aftur beint fordæmi pess síðarnefnda við túlkun á efnislega sambærilegum reglum EES-réttar.

Að pessu sögðu verður pó að leggja áherslu á pað sem segir í upphafi kaflans um að alltaf purfi að kanna hvort mismunandi próun reglna hafi átt sér stað innan ESB annars vegar og EES hins vegar, ýmist vegna breytinga á sáttmála ESB, afleiddrar löggjafar eða fyrir áhrif samninga einstakra ríkja, tveggja eđa fleiri sbr. áđurnefndan dóm Evrópudómstólsins frá árinu 2009.

\section{Frelsisákvæði EES-réttar og beinir skattar}

Eins og fram hefur komið er ekki fjallað um beina skatta í EES-samningnum og engar tilskipanir á pví sviði hafa verið teknar upp í samninginn, hvorki við undirritun hans né síðar par sem pær teljast ekki vera hluti samningsins. ${ }^{21}$ Hins vegar eru í samningnum ákvæði sem varða óbeina skatta sem miða að pví að tryggja frjálst flæði vöru, m.a. 14. gr. samningsins sem leggur bann við mismunandi skattlagningu innlendra og erlendra vara. Í áðurnefndum dómi hæstaréttar, hrd. 2003.2045, var niðurstaðan sú að reglur um misháan virðisaukaskatt á bækur á íslensku annars vegar og erlendum tungumálum hins vegar væri óbein mismunun sem stríddi gegn 2. mgr. 14. gr. EES-samningsins.

Við gildistöku EES-samningsins var talið að samningurinn hefði ekki áhrif á reglur um beina skatta. Í málflutningi fyrir EFTA-dómstólnum í máli nr. E-6/98, par sem deilt var um fyrirkomulag svæðisbundins tryggingargjalds í Noregi, héldu norsk stjórnvöld pví pannig fram að umdeildar reglur, sem stefnandi taldi stríða gegn ríkisstyrkjaákvæðum EES-samningsins, væru hluti af almennu skattkerfi landsins og féllu sem slíkar utan gildissviðs samningsins. ${ }^{22}$ Dómurinn féllst ekki á pessi rök og segir m.a. í niðurstöðu sinni að ekki beri að halda skattareglum utan við samninginn, líta verði til áhrifa reglnanna en ekki heitis peirra pegar metið er hvort pær stríði gegn almennum ákvæðum EES-samningsins. ${ }^{23}$ Sama afstaða kemur fram í

21 Sjá hins vegar Jón Elvar Guðmundsson, „European tax law in the relations with the EFTA countries, " um áhrif EES-réttar á afleidda löggjöf ESB á sviði beinna skatta. Hann telur að Evrópusambandsríkjunum sé skylt að veita EES-ríkjum sömu meðferð og ESB-ríkjum á grundvelli slíkrar löggjafar.

22 Sjá nánar greinar 24-26.

23 Grein 34. 
máli E-5/04, Fesil ASA og Finnfjord Smelteverk AS gegn ESA, og í máli E-1/04, Fokus bank-málinu. Í síðarnefnda málinu tekur dómurinn fram að pótt skattkerfi falli að meginstefnu utan sviðs samningsins verði aðildarríki engu að síður að beita skattlagningarrétti sínum í samræmi við almennar reglur samningsins. ${ }^{24}$ Pessi niðurstaða EFTA-dómstólsins er í samræmi við margstaðfesta afstöðu Evrópudómstólsins. ${ }^{25}$

\subsection{Almennt um bann við mismunun}

Bann við mismunun á grundvelli ríkisfangs er grundvallarstef í EES-rétti. Bannið kemur fram í 4. gr. EES-samningsins par sem segir að hvers konar mismunun á grundvelli ríkisfangs sé bönnuð á gildissviði samningsins nema annað leiði af einstökum ákvæðum hans. Ákvæði petta er efnislega samhljóða núverandi 18. gr. ESB. Í skattarétti hafa pessi almennu ákvæði um bann við mismunun ekki mikla sjálfstæða pýðingu par sem reglur innri markaðarins, einkum reglurnar um fjórfrelsið, ganga framar peim. ${ }^{26}$ Pví eru skattamál yfirleitt rekin á grundvelli brota á reglum innri markaðarins, einhvers frelsisákvæðanna eða samkeppnisreglum. Fjórfrelsisreglurnar fela í sér víðtækara bann en felst í banni við mismunun par sem ákvæðunum er einnig ætlað að koma í veg fyrir að aðildarríkin hindri eða takmarki pað frelsi sem ákvæðin fjalla um.

Í banni við mismunun felst bæði að bannað er að mismuna eða meðhöndla aðila í sömu stöðu á mismunandi hátt án gildra efnisraka og jafnframt er bannað að afgreiða ósambærileg mál með sama hætti, án gildra efnisraka. ${ }^{27}$ Bannið í 4. gr. EES (18. gr. ESB) er bann við mismunun á grundvelli ríkisfangs. Hvað fyrirtæki varðar, pá er átt við pað hvar fyrirtæki hefur skráða skrifstofu eða eftir atvikum hvar yfirstjórn pess eða aðalstöðvar eru staðsettar, sbr. 34. gr. EES-samningsins. ${ }^{28}$ Bannið gildir almennt á tvo vegu; ríkjum er bæði bannað að mismuna eigin fyrirtækjum sem og erlendum, p.e. brotið getur falist í pví að reglurnar torveldi fyrirtækjum ríkis að stunda starfsemi annars staðar á EES-svæðinu eða að reglurnar beinist að erlendum fyrirtækjum sem stunda starfsemi í viðkomandi ríki. ${ }^{29}$

24 Grein 20.

25 Sjá t.d. grein 29 í máli C-446/03, Marks \& Spencer.

26 18. gr. ESB er almenn regla (lex generalis) um bann við mismunun á grundvelli ríkisfangs en önnur ákvæði sáttmálans, s.s. fjórfrelsisákvæðin, eru sérreglur (lex specialis) að pví er varðar gildissvið peirra ákvæða. Petta pýðir að einstök frelsisákvæði ganga framar almennu reglunni en hins vegar er aðferðin við að meta hvort um mismunun sé að ræða sú sama hvort sem byggt er á almennri reglu eða sérákvæði. Sjá Jeppe R. Stokholm, EU skatteret, bls. 138 o.áfr.

27 Stefán Már Stefánsson, „Leyfilegar takmarkanir á fjórfrelsisákvæðum EB/EES réttar, “ bls. 412.

28 Sjá líka 20. grein í máli C-212/97, Centros, par sem segir m.a.: „The location of their registered office, central administration or principal place of business serves as the connecting factor with the legal system of a particular State in the same way as does nationality in the case of a natural person."

29 Sjá t.d. grein 42 í máli C-9/02, Lasteyrie du Saillant, og dóma sem par er vísað til. 
Með banni við mismunun er ekki bara átt við augljósa mismunun byggða á ríkisfangi heldur hefur Evrópudómstóllinn einnig lýst peirri reglu að sérhver óbein eða dulin mismunun, sem í framkvæmd leiðir til sömu niðurstöðu, sé brot á reglunni um bann við mismunun. ${ }^{30}$ Óbein eða dulin mismunun felst pá í pví að beita reglum sem ekki byggja á pjóðerni skattgreiðenda, eða í tilviki fyrirtækja á heimilisfesti peirra, til að ákvarða mismunandi skattgreiðslur sem í reynd leiða til pess að borgarar annarra ríkja er mismunað gagnvart eigin borgurum ríkisins. Í máli C-195/90, Framkvæmdastjórnin gegn Pýskalandi, reyndi á lögmæti reglna varðandi skattlagningu pungaflutninga. Skattur var lagður á notkun atvinnubifreiða á pýskum vegum en samhliða upptöku skattsins voru gerðar aðrar skattalagabreytingar sem miðuðu að pví að létta af pýskum atvinnubifreiðafyrirtækjum skatti jafnháum nýju álögunum. Í raun hafði skattlagningin pví einungis áhrif á skattbyrði erlendra fyrirtækja og bætti samkeppnisstöðu pýskra fyrirtækja sem pví nam. Petta taldi dómstóllinn að bryti í bága við reglur bandalagsins um flutningastarfsemi. ${ }^{31}$ Í máli C-324/00, Lankhorst-Hohorst, var niðurstaða dómstólsins byggð á sömu sjónarmiðum.

Pá er stundum greint á milli pess sem kallað er lóðrétt og lárétt mismunun. Með lóðréttri mismunun (d. vertikal forskelsbehandling, e. vertical discrimination) er átt við mismunun sem byggir á pví að starfsemi, sem fer fram innan viðkomandi ríkis, er skattlögð með hagfelldari hætti en sams konar starfsemi sem fer fram að hluta til í öðru aðildarríki. Lóðrétt mismunun felur pví alltaf í sér skoðun á einhverri efnahagslegri starfsemi sem fer fram í fleiri en einu aðildarríki. ${ }^{32}$ Lárétt mismunun felur hins vegar í sér mismunun byggða á öðru en staðsetningu eða heimilisfesti, s.s ef reglur eru mismunandi eftir félagaformi, t.d. pannig að fyrirtæki, sem stofnar dótturfélag í öðru ríki fær aðra skattlega meðferð í heimaríki sínu heldur en fyrirtæki í sambærilegri stöðu sem stofnar útibú í sama priðja ríki. Hér er pað ekki skilgreiningaratriði að starfsemin fari fram í fleiri en einu ríki heldur hitt í hvaða félagaformi hún er stunduð.

\subsection{Hvenær er um mismunun að ræða?}

Útgangspunkturinn við mat á pví hvort brotið er gegn banni við mismunun á sviði skattaréttar er að kanna hvort staða aðila, sem bornir eru saman, sé sambærileg pví bann við mismunun felst í pví að ekki má mismuna aðilum sem eru í sambærilegri stöðu. Рað getur hins vegar verið nokkuð snúið að lesa út úr dómum Evrópudóm-

30 Omar G. Dajani o.fl., EØS-avtalen og norsk skatterett, bls. 59, par sem vísað er til máls C-360/89, Framkvæmdastjórnin gegn Ítalíu.

31 Pótt málið varði ekki brot á fjórfrelsisreglunum hefur pað pýðingu hér varðandi pað hvernig mismunun getur talist andstæð samningnum pótt hún sé óbein afleiðing einstakrar skattlagningar. Sjá nánar Nikolaj Vinther og Erik Werlauff, „Hvad bør Danmark gøre ved problemet „tynd kapitalisering" eftir dommen in Lankhorst-Hohorst?"

32 Jeppe R. Stokholm, EU skatteret, bls. 140. 
stólsins og EFTA-dómstólsins, hvaða pættir eru valdir til að bera saman og hvernig sá samanburður fer fram.

Hvað einstaklinga varðar pá hefur Evrópudómstóllinn slegið pví föstu að peir sem eru heimilisfastir og peir sem ekki eru heimilisfastir í tilteknu ríki, geti vanalega ekki talist vera í sambærilegri stöðu í upprunalandsríkinu. Petta er í samræmi við viðurkennda reglu á sviði alpjóðlegs skattaréttar að greint er á milli peirra sem bera fulla og takmarkaða skattskyldu eftir pví hvar peir eru heimilisfastir. Petta kemur m.a. fram í Schumacker málinu, C-279/93. Petta sjónarmið skýrist af pví að venjulega afla peir, sem ekki eru heimilisfastir í viðkomandi ríki, einungis hluta eða jafnvel óverulegs hluta tekna sinna í viðkomandi ríki en hafa aðalframfærslu af tekjum í sínu heimaríki. Er pá talið rétt að í heimilisfestisríki sé beitt reglum sem lúta að persónuafslætti, barnabótum og öðrum skattareglum sem lúta að persónulegri stöðu viðkomandi skattgreiðanda. Schumacker málið varðaði tekjuskatt einstaklings. Sama niðurstaða var í máli D, C-376/03 sem laut að eignarskatti. Prátt fyrir ofangreint getur í vissum tilvikum verið um óheimila mismunun að ræða ef afleiðingar reglnanna, sem til skoðunar eru, teljast ósamrýmanlegar ESB-rétti óháð heimilisfesti skattgreiðanda. ${ }^{33}$

Ekki er hægt að beita sömu rökum fullum fetum í samanburði á stöðu fyrirtækja með heimilisfesti utan og innan tiltekins aðildarríkis. Í máli Marks \& Spencer segir að heimilisfesti skattaðila geti mögulega haft áhrif á skattskyldu hans en svo er bætt við, í grein 38: „Í sérhverju tilviki er nauðsynlegt að skoða hvort sú staðreynd að skattaívilnun standi eingöngu heimilisföstum skattgreiðendum til boða sé byggð á viðeigandi hlutlægum páttum sem réttlætt geta mismunandi skattlagningu. “34

Í málum sem lúta að skattlagningu arðgreiðslna milli fyrirtækja hefur í nokkrum málum reynt á reglur landsréttar sem skattleggja með mismunandi hætti greiðslur til fyrirtækja eftir pví hvort pau eru heimilisföst í viðkomandi ríki eða ekki. Í tveimur dómum Evrópudómstólsins (C-170/05, Denkavit og C-379/05, Amurta) og einum dómi EFTA-dómstólsins (E-1/04, Fokus bank) hefur niðurstaðan verið sú að pessi fyrirtæki teljast vera í sambærilegri stöðu. Í Fokus bank-málinu virðist markmið skattlagningarinnar hafa skipt máli í pessum samanburði. Í málinu kom fram að markmið skattaafsláttar (eða frádráttar) á arðgreiðslum til fyrirtækja í Noregi væri að koma í veg fyrir efnahagslega tvísköttun arðstekna. Par sem sýnt var fram á að slík efnahagsleg tvísköttun væri möguleg, bæði í tilviki peirra fyrirtækja sem voru heimilisföst í Noregi og utan Noregs, var talið að reglan yrði að ná til fyrirtækja óháð heimilisfesti; annað væri mismunun aðila í sambærilegri stöðu. ${ }^{35}$ Í ofangreindum

33 Jeppe R. Stokholm, EU skatteret, bls. 160.

34 Mál C-446/03. Orðrétt segir í 38. gr. dómsins: „In each specific situation, it is necessary to consider whether the fact that a tax advantage is available solely to resident taxpayers is based on relevant objective elements apt to justify the difference in treatment."

35 Grein 30 í dóminum og umfjöllun Barry Larking, „Fokus Bank: The end of withholding tax as we know it?“ einkum bls. 71-72. Fleiri dómar Evrópudómstólsins eru á svipuðum nótum. Hins vegar eru einstakir nýrri dómar ekki alveg á sömu línu, sbr. einkum C-374/04, ACT Group Litigation og C-376/03, D. 
premur málum var um að ræða arðgreiðslur til fyrirtækja sem ekki voru með fasta starfsstöð í pví ríki sem arðgreiðslurnar voru greiddar.

Í máli Marks \& Spencer, C-446/03, áleit dómstóllinn að breskt móðurfélag, sem ætti dótturfélag heimilisfast í Bretlandi, og annað sem ætti dótturfélag í öðru ESB-ríki væru í sambærilegri stöðu. Hér sem endranær parf hins vegar að gæta að jafnvæginu milli skyldu aðildarríkja til að gæta jafnræðis og torvelda ekki frelsisákvæðin annars vegar og rétt peirra til að ákveða sjálf skattlagningu innan sinnar lögsögu. Í pví sambandi má benda á mál ACT Group Litigation, C-374/04, par sem niðurstaðan var m.a. sú að aðildarríki var talið heimilt að binda frádrátt frá skatti vegna móttekinna arðgreiðslna við móðurfélög heimilisföst í pví ríki. Sú niðurstaða byggir á pví að gagnstæð niðurstaða hefði leitt til pess að ríkinu hefði í reynd verið ómögulegt að skattleggja hagnað heimilisfastra dótturfélaga og ganga pannig gegn sjálfsákvörðunarrétti peirra. $^{36}$

Mat á pví hvort aðilar teljist vera í sambærilegri stöðu er nátengt mati á pví hvort takmarkanir á frelsisákvæðum séu réttlætanlegar. Í eldri dómum Evrópudómstólsins dvelur dómurinn ekki lengi við pessa spurningu heldur gengur út frá pví að tilteknar aðstæður séu sambærilegar og einbeitir sér pví frekar að pví hvort lögmæt sjónarmið geti réttlætt mismunandi skattlagningu. Í nýrri dómum fer meira fyrir umfjöllun um samanburð á stöðu skattaðila. Ef niðurstaða dómsins er sú að aðilar teljist ekki vera í sambærilegri stöđu fer ekki fram frekari skoðun á pví hvort um ólögmæta mismunun eða takmörkun á fjórfrelsisákvæðum sé að ræða. Michael Lang heldur pví fram að dómstólinn virðist líta svo á að aðildarríkum sé pá heimilt að haga skattareglum að vild. Hann gagnrýnir pessa nálgun dómstólsins og telur að grunnsjónarmið, sem lúta að réttlætanlegum takmörkunum, og meðalhófsreglan ættu að leiða til pess að dómstóllinn skoði einnig áhrif skattareglna pótt aðstæður skattaðila séu ekki að fullu sambærilegar. Með öðrum orðum pá verði að vera samhengi á milli pess hve ólík aðstaðan er og pess hve mikill munur er á skattareglum sem gilda. ${ }^{37}$

\section{3. Ólögmætar takmarkanir á fjórfrelsisreglum}

Markmið reglna um innri markað ESB er að afnema allar hindranir á frjálsum vöruflutningum, fólksflutningum, pjónustustarfsemi og fjármagnsflutningum. Eins og áður segir pá hafa almenn ákvæði um bann við mismunun ekki mikla sjálfstæða pýðingu í skattarétti par sem reglur innri markaðarins ganga framar peim. Pví eru skattamál yfirleitt rekin á grundvelli brota á reglum innri markaðarins, einhvers frelsisákvæðanna eða samkeppnisreglum.

36 Sjá greinar 58-60 í dóminum. Í „Denkavit Internationaal: the balance between fiscal sovereignty and the fundamental freedoms?" bendir Frans Vanistendael á að í pessum dómi er borin saman aðstaða tveggja ríkja með tilliti til pess hvort pau teljist vera í sambærilegri stöðu.

37 Michael Lang, „Direct taxation: is the ECJ heading in a new direction?" bls. 21 o.áfr. og eigin rit sem hann vísar til í neðanmálsgreinum 12-14. 
Mörg ákvæði sem varða innri markaðinn kveða á um bann við mismunun á grundvelli ríkisfangs en í sumum ákvæðum er fjallað um bann við hindrunum eða takmörkun á frelsi og enn önnur styðjast við hvort tveggja. ${ }^{38}$ Eins og áður sagði hefur Evrópudómstóllinn ekki einungis talið að bein mismunun brjóti í bága við ákvæði sáttmálans heldur einnig óbein eða dulin mismunun. Jafnframt hefur dómstóllinn talið ýmsar takmarkanir og hindranir fyrir pví að nýta frelsisákvæði samningsins andstæðar ákvæðum hans.

Munurinn á banni við mismunun og banni við takmörkunum á fjórfrelsisákvæðunum er sá að bann við mismunun er beint gegn reglum aðildarríkja sem fela í sér mismunandi meðferð sambærilegra tilvika eða eins meðferð ólíkra tilvika. Banni við takmörkunum er hins vegar beint gegn ráđstöfunum aðildarríkjanna sem geta hindrað notkun frelsisákvæða samningsins eða gert pað óaðgengilegra fyrir aðila að nýta sér pau. Bann við takmörkunum frelsisákvæðanna gengur pví lengra en bann við mismunun par sem pað er nægjanlegt að aðgerðir eða reglur feli í sér að pað sé minna aðlaðandi að nýta sér frelsisákvæðin. Bann við takmörkunum getur með öðrum orðum átt við pótt ekki sé um eiginlega mismunun að ræða. Banni við mismunun er einungis unnt að beita par sem hægt er að sýna fram á að mismunandi reglur gildi um vörur, einstaklinga, pjónustu, félög eða fjármagn á grundvelli uppruna (ríkisfangs). Mismunun er í eðli sínu líka takmörkun og pví má segja að bann við mismunun sé nokkurs konar hlutmengi í reglu um bann við takmörkun. Bann við mismunun er par með lágmarkskrafa sem varðar allar reglur um innri markaðinn og vandinn er pví að ákveða hvenær ákvæði gengur lengra og felur einnig í sér bann við takmörkunum.

Fræðilega er greint á milli pess að ráðstafanir feli í sér bann við mismunun annars vegar, og hins vegar að regla takmarki eða hindri notkun fjórfrelsisins par sem aðferðirnar við að meta lögmæti slíkra reglna er mismunandi. Ef fyrirkomulag í aðildarríki er talið fela í sér mismunun á grundvelli pjóðernis (staðfestu í tilviki fyrirtækja) verður slíkt einungis talið réttlætanlegt ef pað styðst við eitthvert undantekningarákvæða sáttmálans sjálf sem varðar vernd almannahagsmuna. Slíkt ákvæði er m.a. að finna í 36. gr. ESB par sem fjallað er um að ákvæði um frjálsa vöruflutninga komi ekki í veg fyrir takmarkanir sem réttlætast af almennu siðferði, allsherjarreglu,

38 Auk 18. gr. ESB felur 45. gr. í sér bann við allri mismunun sem byggir á ríkisfangi launpega að pví er lýtur að atvinnu og starfs- og ráðningarskilyrðum. Á hinn bóginn er ákvæði 34. gr. og fleiri greinar er varða vöruflutninga sett fram sem bann takmörkunum par sem lagt er bann við magntakmörkunum á innflutningi vara og aðrar ráđstafanir með samsvarandi áhrif. Pá er ákvæði 49. gr. um staðfesturétt bæði sett fram sem bann við takmörkun, sbr. 1. mgr. par sem segir að bannað sé að leggja höft á rétti ríkisborgara aðildarríkis til að öðlast staðfestu á yfirráðasvæði annarra aðildarríkja og bann við mismunun, sbr. 2. mgr. par sem kveðið er á um að staðfesturétturinn feli í sér að sömu reglur skuli gilda um ríkisborgara innan og utan aðildarríkis. Ákvæði 63. gr. um frelsi til fjármagnsflutninga er sett fram sem bann við takmörkunum. Pað er jafnframt eina greinin sem nær til ríkja utan innri markaðarins. Sjá nánar Karsten Engsig Sørensen og Poul Runge Nielsen, EU-retten, bls. 236 og 237. 
almannaöryggi, vernd lífs og heilsu manna eða dýra eða gróðurvernd, vernd pjóðarverðmæta, er hafa listrænt, sögulegt eða fornfræðilegt gildi, eða vernd eignarréttinda á sviði iðnaðar og viðskipta. Sambærilegt ákvæði er í 13. gr. EES-samningsins. Petta á sérstaklega við ef um beina mismunun er að ræða. ${ }^{39}$ Fyrirkomulag sem felur í sér takmarkanir á frelsisákvæðum samningsins parfnast hins vegar ítarlegri skoðunar par sem slíkt kann að vera heimilt á grundvelli ólögfestra sjónarmiða um réttlætanlegar takmarkanir á frelsisákvæðunum. ${ }^{40}$ Í framkvæmd getur pó verið örðugt að greina á milli brota sem byggja á mismunun annars vegar og takmörkunum hins vegar, sérstaklega hvað varðar óbeina mismunun. Í pví efni verður að athuga að frelsisákvæði sáttmálans fela flest í sér hvort tveggja, bann við mismunun og bann við takmörkunum svo sem að framan greinir auk pess sem úrlausnir dómstólsins eru ekki alltaf í samræmi við framangreinda aðgreiningu í fræðikenningum. Pannig hefur dómstóllinn í sumum tilvikum metið hvort brot, sem byggja á mismunun, megi réttlæta á grundvelli ólögfestra sjónarmiða sem sögð eru að eigi einungis að koma til skoðunar að pví er varðar hindranir á fjórfrelsisákvæðum sáttmálans án pess að um eiginlega mismunun sé að ræða. ${ }^{41}$ Pannig hefur verið bent á að í Bachman-málinu var talið að um óbeina mismunun væri að ræða, sem engu að síður var talin réttlætanleg á grundvelli ólögfestra sjónarmiða um brýna almannahagsmuni en í máli Royal Bank of Scotland var talið að engin ólögfest réttlætingarsjónarmið kæmu til skoðunar par sem um mismunun væri að ræða. ${ }^{42}$ Pví verður að hafa í huga að pau sjónarmið sem lýst er í 3. kafla, um réttlætanlegar takmarkanir á fjórfrelsisreglunum geta átt við bæði varðandi mál sem lúta að óbeinni mismunun og takmörkunum á fjórfrelsinu án pess að um slíka mismunun sé að ræða. ${ }^{43}$

Hvað skattamál varðar pá horfir dómstóllinn yfirleitt einangrað á umdeild skattaákvæði, p.e. hann tekur ekki tillit til pess pótt sýnt sé fram á að heildarskattlagning erlends fyrirtækis sé sambærileg eða eins og um innlent fyrirtæki sé að ræða. petta kemur fram í Avoir Fiscal-málinu, sem er eitt af fyrstu skattamálum sem komu til kasta Evrópudómstólsins og hefur verið vikið að pessu í nokkrum málum síðar. Má par nefna dóm í máli C-330/91, Commerzbank. Pýskur banki sem rak útibú í Bretlandi átti ekki rétt á sama skattahagræði og félög sem skráo voru par í landi. Talið var að pessar reglur brytu gegn 43. gr. EB (nú 49. gr. ESB sem er samsvarandi 31. gr. EES) um staðfesturétt og breytti engu pótt sýnt væri fram á að önnur ákvæði

39 Karsten Engsig Sørensen og Poul Runge Nielsen, EU-retten, bls. 244-245.

40 Ben J. M. Terra og Peter J. Wattel, European tax law, bls. 55.

41 Karsten Engsig Sørensen og Paul Runge Nielsen tala í EU-retten annars vegar um að óbein mismunun sé skoðuð út frá pví hvort málefnalegar forsendur (d. saglige grunde) liggi til grundvallar mismunandi meðferð og hins vegar að brýnir almannahagsmunir (d. tvingende almene hensyn) geti réttlætt takmarkanir á frelsisákvæðunum en taka jafnframt fram að sterk líkindi séu með báðum aðferðunum. Sjá bls. 245.

42 Mál C-204/90, Bachman, og C-311/97, Royal Bank of Scotland, og umfjöllun um ósamkvæmni dómstólsins í heimild sem vísað er til í neðanmálsgrein 40 hér að ofan.

43 Sjá nánar Jeppe R. Stokholm, EU Skatteret, bls. 490 o.áfr. 
breskra skattalaga væru peim hagfelldari einmitt vegna pess að fyrirtækið var rekið sem útibú en ekki sem sjálfstætt félag par í landi. Petta kemur einnig fram í SaintGobain-málinu, sem varðaði mismunandi skattalega meðferð arðgreiðslna milli félaga, eftir pví hvort pau væru útibú erlendra fyrirtækja eða sjálfstæð pýsk félög. Um pað sjónarmið pýskra skattyfirvalda, að skattlagningu arðgreiðslna yrði að skoða í samhengi við skattlagningu arðs á síðari stigum í höndum pýskra félaga, sagði dómurinn: „Í pessu sambandi verður að athuga að mismunandi skattlagningu heimilisfastra fyrirtækja og útibúa er á hinn bóginn ekki hægt að réttlæta með öðru hagræði sem útibú njóta umfram heimilisföst fyrirtæki sem, að mati pýskra stjórnvalda, vegi upp óhagræði pess að njóta ekki pess skattalega hagræðis sem um er deilt. Jafnvel pótt slíkt hagræði væri til staðar, getur pað ekki réttlætt brot á skyldu samkvæmt 52. gr EB til að veita peim sömu meðferð að landsrétti varðandi pá skattaívilnun sem um ræðir [...]“44

Ípyngjandi skrifræðisreglur geta falið í sér ólögmætar takmarkanir á sviði skattaréttar. Рað getur með öðrum orðum verið um ólögmæta hindrun að ræða pótt ekki sé munur á skattskyldu innlendra fyrirtækja og hinna sem staðfestu eiga í öðru ESB-ríki skattskylda. Dæmi um petta er C-250/95, Futura Participations, par sem kröfur til framsetningar bókhalds gagnvart fyrirtækjum sem staðfestu höfðu í öðru ESB-ríki póttu ganga lengra en nauðsyn krafði til að ná yfirlýstu markmiði peirra um að halda uppi virku skatteftirliti.

Pá getur bann við mismunun bæði takmarkað heimildir aðildarríkja til að setja reglur sem hindra eigin ríkisborgara í að leita til annarra ESB-ríkja jafnt og reglur sem torvelda borgurum annarra ríkja að athafna sig í viðkomandi ríki. Svokallaður útgönguskattur (e. exit tax) er dæmi um slíka skattlagningu. Á hinn bóginn er reglum innri markaðarins ekki ætlað að koma í veg fyrir mismunun sem birtist í pví að reglur, sem einungis varða starfsemi innan tiltekins ESB-ríkis, séu óhagfelldari peim sem par starfa heldur en reglur sem gilda um starfsemi sem fram fer yfir landamæri. Slíkar reglur gætu hins vegar eftir atvikum talist fela í sér skaðlega skattasamkeppni eða ólögmæta ríkisstyrki.

\subsection{TengsI tvísköttunarsamninga við ESB/EES-rétt}

Í nokkrum málum fyrir Evrópudómstólnum og a.m.k. í einu máli fyrir EFTAdómstólnum (Fokus bank) reyndi á samspil tvísköttunarsamninga og Evrópureglna. Ýmis tilvik geta komið upp í pessu sambandi. Meðal annars hafa vaknað spurningar

44 Í 53. gr. máls C-307/97, Saint-Gobain stendur: „In this regard, it must be observed that the difference in tax treatment between resident companies and branches cannot, however, be justified by other advantages which branches enjoy in comparison with resident companies and which, according to the German Government, will compensate for the disadvantages of not being allowed the tax concessions in question. Even if such advantages exist, they cannot justify breach of the obligation laid down in Article 52 of the Treaty to accord the same domestic treatment concerning the tax concessions in question $[\ldots]^{\prime \prime}$ 
varðandi pau tilvik að tvísköttunarsamningar milli tveggja ESB-ríkja leiða til pess að fyrirtæki í peim ríkjum eru skattlögð með hagfelldari hætti en fyrirtæki í öðrum ESBríkjum. Pessi áhrif tvísköttunarsamninga hefur dómstóllinn ekki talið fela í sér brot á frelsisákvæðum ESB-sáttmálans. ${ }^{45}$ Pá hefur reynt á pað hvaða áhrif pað hefur á mat á landsreglum, sem fela í sér einhverja mismunun á milli fyrirtækja innan og utan viðkomandi ríkis, að ákvæði tvísköttunarsamninga geti leitt til pess að sú mismunun verði leiðrétt í heimaríki viðkomandi fyrirtækis. Einnig hefur verið spurt hvort pað skipti máli, pegar slík heimildarákvæði eru í tvísköttunarsamningum, ${ }^{46}$ hvort pau komi að raunverulegu gagni í viðkomandi tilviki.

Í Denkavit-málinu, C-170/05, var óskað forúrskurðar Evrópudómstólsins varðandi skattlagningu arðgreiðslna hollensks móðurfélags frá dótturfélagi í Frakklandi. Frönsk skattalöggjöf gerði ráð fyrir pví að arðgreiðslur til félaga sem ekki hefðu skattalegt heimilisfesti í Frakklandi væru skattlagðar á meðan frönsk fyrirtæki voru að mestu leyti undanpegin skattgreiðslum í sömu tilvikum. Skatthlutfall arðgreiðslna til erlendra félaga var 25\% en á grundvelli tvísköttunarsamnings milli Hollands og Frakklands var skattur hollenskra fyrirtækja takmarkaður við 5\% enda væri eignarhluti peirra í dótturfélaginu a.m.k. 25\%. Petta fyrirkomulag var talið brjóta í bága við 43. gr. EB (nú 49. gr. ESB). Fyrir lá að Denkavit gæti ekki fengið afslátt á skattgreiðslum í Hollandi á móti franska skattinum á grundvelli 24. gr. tvísköttunarsamningsins par sem móttekinn arður var ekki skattlagður sérstaklega samkvæmt hollenskum skattalögum. Frönsk stjórnvöld héldu pví fram að í samræmi við grunnreglur alpjóðlegs skattaréttar, pá væri pað hlutverk heimilisfestisríkis að leiðrétta áhrif tvísköttunar. Evrópudómstóllinn féllst ekki á pessa málsvörn og sagði að frönsk stjórnvöld gætu ekki vísað til tvísköttunarsamninga til að firra sig ábyrgð á skyldum samkvæmt sambandsrétti. Jafnframt segir dómurinn að beiting umrædds tvísköttunarsamnings og hollenskra skattareglna komi ekki í veg fyrir að hollensk fyrirtæki sæti skattlagningu sem sé pyngri en frönsk fyrirtæki sæti og pví feli franskar skattareglur í sér ólögmæta takmörkun á staðfesturétti umrædds fyrirtækis. ${ }^{47}$ Álykta má frá pessum dómi að ekki einungis purfi að skoða löggjöf pess ríkis sem leggur á umdeildan skatt heldur einnig ákvæði tvísköttunarsamninga og löggjafar heimaríkis pegar brot á fjórfrelsisákvæðunum eru metin. Mismunun sem byggir á pví að upprunaríkið skattleggur tekjur erlendra aðila pyngra en innlendra fyrirtækja kann að mega réttlæta

45 Mál C-376/03, D. Leyst er úr málinu á grundvelli pess að menn teljist ekki vera í sambærilegri stöðu, p.e. peir sem falla undir tiltekinn tvísköttunarsamning og hina sem ekki gera pað. Sjá grein 61. Niðurstaðan er umdeild.

46 Er pá átt við petta: Í tvísköttunarsamningi er ákvæði pess efnis að ríki A megi leggja allt að 10\% skatt á arðgreiðslur til aðila í ríki B og jafnframt að ríki B sé skuldbundið til að veita frádrátt á móti pessum skatti ef pað skattleggur sömu tekjur. Slíkt ákvæði hefur í raun enga pýðingu nema í peim tilvikum að ríki B skattleggi arðinn samkvæmt eigin skattalögum pví að öðrum kosti er engin skattur til að heimila frádrátt frá.

47 Sjá greinar 51-55 í dóminum. 
með pví að tvísköttunarsamningar og löggjöf heimaríkis veiti afslátt á móti. ${ }^{48}$ Í Denkavit-málinu lá fyrir að sú var ekki raunin.

Hins vegar var dómur EFTA-dómstólsins í máli Fokus bank ekki í fullu samræmi við ofangreinda niðurstöðu. Með líkum hætti og í Denkavit reyndi á lögmæti afdráttarskatts á arðgreiðslur erlendra móðurfélaga fyrirtækja í Noregi. Varðandi samspil tvísköttunarsamninga og fjórfrelsisreglna EES-samningsins, taldi EFTAdómstóllinn ákvæði tvísköttunarsamninga ekki skipta máli við mat á lögmæti norskra reglna óháð pví hvort ákvæði peirra í reynd leiddu til pess að erlend fyrirtæki fengju leiðréttingu tvísköttunar í heimilisfestisríki sínu. ${ }^{49}$ Í áliti aðallögmanns í Denkavit-málinu er gerð ítarleg grein fyrir pví af hverju pessu sjónarmiði er hafnað og byggt á pví að horfa verði heildstætt á skyldur heimilisfestisríkis og upprunaríkis pegar frelsisákvæði samningsins eru metin og jafnframt að horfa verði til raunverulegra efnahagslegra áhrifa skattkerfa við tilteknar aðstæður. ${ }^{50}$

\section{Réttlætanlegar takmarkanir}

Ef niðurstaða athugunar Evrópudómstólsins er sú að reglur takmarki með einhverjum hætti möguleika til að nýta fjórfrelsisákvæði samningsins, eða aðrar grundvallarreglur hans, eru talsverðar líkur á að slíkar reglur teljist andstæðar honum. Ákveðin atriði geta hins vegar réttlætt takmarkanir eða hindranir á beitingu fjórfrelsisákvæðanna. ${ }^{51}$ Pannig er ekki nóg að leiða í ljós að reglan feli í sér takmarkanir heldur parf líka að athuga hvort einhver lögmæt sjónarmið geti réttlætt pessar takmarkanir. Pau sjónarmið sem dómstóllinn hefur tekið til greina í pessu sambandi eru pau sem byggja á brýnum almennum hagsmunum, ${ }^{52}$ markmið peirra verða að vera skýr og reglurnar verða að vera pannig úr garði gerðar að tryggt sé að markmiðin náist. Loks

48 Ályktun pessi er einnig í samræmi við pað sem fram kemur í Amurta málinu, C-379/05, par sem dómstóllinn gerir greinarmun á pví hvort mismunandi skattlagning í einu ríki sé leiðrétt í heimaríki viðkomandi fyrirtækis með einhliða aðgerðum (p.e. löggööf) eða á grundvelli tvísköttunarsamninga. Sjá grein 84 í dóminum.

49 Sjá grein 38 í dóminum.

50 Sjá greinar 35-39 í áliti lögmannsins og neðanmálsgrein 28 í álitinu par sem hann fjallar um Fokus bank-málið.

51 Eins og áður sagði er oft óljós munurinn á meðferð mála sem varða annars vegar óbeina mismunun og hins vegar takmarkanir á fjórfrelsinu. Ýmsir halda pví fram að mat dómstólsins á pví hvort um mismunun sé að ræða fari fram með sama hætti og pegar dómstóllinn metur hvort brýnir almannahagsmunir geti réttlætt takmarkandi reglur. Í einhverjum dómum eru jafnvel notuð hugtök eins og brýnir almannahagsmunir pegar matið á málefnalegum forsendum fer fram og ruglar petta umræðuna. En jafnvel pótt dómstóllinn beiti líkum aðferðum í báðum tilvikum verður að undirstrika að hann er strangari í mati sínu pegar kemur að ætluðu broti sem byggir á mismunun heldur en broti sem lýtur að takmörkunum. Sjá Karsten Engsig Sørensen og Poul Runge Nielsen, EU-retten, bls. 244-246.

52 Enska: overriding public interest, danska: tvingende almene hensyn. Stefán Már Stefánsson fjallar um hugtakið sem óhjákvæmilegar pjóðfélagsparfir í almannapágu i „,Leyfilegar takmarkanir á fjórfrelsisákvæðum EB/EES réttar,“ bls. 418-420. 
er nauðsynlegt skilyrði lögmætis að takmarkanir gangi ekki lengra en nauðsyn krefur til að ná yfirlýstum markmiðum. Í máli C-250/95, Futura Participations SA eru pessi sjónarmið orðuð svo í 26. grein: „,[...] the imposition of such a condition, which specifically affects companies or firms having their seat in another Member State, is in principle prohibited by Article 52 of the Treaty. It could only be otherwise if the measure pursued a legitimate aim compatible with the Treaty and were justified by pressing reasons of public interest. Even if that were so, it would still have to be of such a nature as to ensure achievement of the aim in question and not go beyond what was necessary for that purpose $[\ldots]^{\text {“53 }}$

Eins og í ESB-sáttmálanum er í EES-samningnum sjálfum að finna nokkur ákvæði sem víkja að undantekningum frá beitingu fjórfrelsisákvæðanna við sérstakar aðstæður, sbr. 33. og 39. gr. að pví er varðar stofnsetningarrétt og viðskipti með pjónustu og 4. gr. tilskipunar ráðsins nr. 88/361 varðandi fjármagnsflutninga og áðurnefnd 13. gr. sem varðar takmarkanir á innflutningi vara. En fæst mál sem koma til kasta Evrópusambandsdómstólsins eða EFTA-dómstólsins varða pessi undantekningarákvæði, heldur hin ólögfestu sjónarmið um brýna almannahagmuni. Í peim málum hafa skattyfirvöld látið reyna á ýmis sjónarmið sem réttlætt geta pær skattareglur sem deilt er um. Evrópusambandsdómstóllinn, og eftir atvikum EFTA-dómstóllinn, hafa pví tekið afstöðu í fjölda tilvika hvort skattareglur byggja á lögmætum eða ólögmætum sjónarmiðum og varpað pannig skýrara ljósi á pær leikreglur sem ber að virða innan skattaréttar. Skipta má sjónarmiðum sem teflt hefur verið fram af hálfu skattkerfisins í prjá höfuðflokka: a) sjónarmið sem lúta að pörfinni fyrir heildstætt skattkerfi og innra samræmi kerfisins, b) pörf fyrir að koma í veg fyrir skattasniðgöngu eða undanskot og loks c) pörf fyrir að halda uppi virku skatteftirliti.

\subsection{Innra samræmi skattkerfisins}

Skattyfirvöld halda pví oft fram að umdeilt fyrirkomulag sé nauðsynlegt til að tryggja innbyrðis samræmi í reglum viðkomandi skattkerfis. Evrópusambandsdómstóllinn hefur verið tregur til að sampykkja reglur sem takmarka fjórfrelsið á pessum grundvelli. Einn af fáum dómum par sem fallist er á sjónarmið skattyfirvalda í pessu sambandi er í Bachmann-málinu, C-204/90. Par var deilt um skattlagningu lífeyrisgreiðslna og pví haldið fram að belgískar reglur par að lútandi brytu í bága við frelsi til fjármagnsflutninga. Reglurnar heimiluðu frádrátt frá skatti vegna iðgjalda til innlendra lífeyrissjóða en ekki erlendra. Greiðslur úr innlendum lífeyrissjóðum voru

53 Til samanburðar eru sömu sjónarmið orðuð pannig í 34. grein í Centros málinu, C-212/97: „,[...] Next, it should be borne in mind that, according to the Court's case-law, national measures liable to hinder or make less attractive the exercise of fundamental freedoms guaranteed by the Treaty must fulfil four conditions: they must be applied in a non-discriminatory manner; they must be justified by imperative requirements in the general interest; they must be suitable for securing the attainment of the objective which they pursue; and they must not go beyond what is necessary in order to attain it $[\ldots]^{\prime \prime}$ 
hins vegar skattskyldar meðan greiðslur úr erlendum lífeyrissjóðum voru pað ekki. Niðurstaða dómstólsins fólst í pví að við „,núverandi próunarstig EB-réttar“ (dómurinn var kveðinn upp í janúar 1992) bæri að líta svo á að samhengisins vegna mætti réttlæta takmörkun pegar um væri að ræða beint samhengi milli annars vegar frádráttar frá skatti vegna innborgunar og skattskyldu við útgreiðslur úr innlendum lífeyrissjóðum og hins vegar engrar frádráttarheimildar við inngreiðslu og engrar skattskyldu við útgreiðslu úr erlendum lífeyrissjóðum. Fordæmisgildi pessa dóms hefur hin síðari ár pó verið dregið í efa. ${ }^{54}$ Vísað er til pessa dóms í fjölmörgum öðrum úrlausnum dómstólsins og svo virðist sem enn sé byggt á peirri meginreglu sem fram kemur í Bachmann-málinu, p.e. réttlæta megi takmarkanir fjórfrelsisins til að tryggja ákveðið samræmi í skattkerfinu en dómurinn leggur pó ítrekað áherslu á að sú heimild sé bundin skilyrðum um að beint samband sé á milli skattskyldu og frádráttar/ skattfrelsis og jafnframt að almenn skilyrði um lögmæti takmarkana séu fyrir hendi. ${ }^{55}$

Takmarkanir á fjórfrelsinu eru ekki heimilar í peim tilgangi að koma í veg fyrir að eitt ríki verði af skatttekjum, t.d. vegna pess að skattskylda færist yfir til annars aðildarríkis Evrópusambandsins eða EES-ríkis. Skattyfirvöld halda pví oft fram að reglur séu nauðsynlegar vegna samhengis eða innra samræmis í skattkerfinu, eða til að koma i veg fyrir undanskot frá sköttum, pegar raunverulegur tilgangur er sá að koma í veg fyrir að viðkomandi ríki verði af skattlagningarrétti. Рað er hins vegar ljóst að Evrópudómstóllinn og EFTA-dómstóllinn hafna takmörkunum á pessum forsendum. Petta kemur t.d. fram í máli C-436/00, X\&Y gegn sænskum skattyfirvöldum. Málavextir voru peir að umdeildar skattareglur heimiluðu ekki frestun á skattlagningu söluhagnaðar hlutabréfa sem seld voru erlendum aðila sem seljandi átti beint eða óbeint hlut í eða til sænsks félags sem erlent félag ætti beint eða óbeint hlut í. Rökin fyrir lagareglunni, sem komu fram í greinargerð með frumvarpi laganna, voru pess efnis að annars væri hætta á að tekjunum yrði skotið undan sænskri skattlagningu. Evrópudómstóllinn taldi að hvorki skráđar undantekningarreglur né óskráđar, byggðar á verndun brýnna almannahagsmuna, réttlættu takmarkanir á fjórfrelsinu á pessum grundvelli. Að auki póttu reglurnar brjóta gegn meðalhófsreglunni par sem pær póttu of víðtækar, pað er of almenns eðlis.

\subsection{Komið í veg fyrir skattasniðgöngu og undanskot}

Evrópudómstóllinn hefur hins vegar viðurkennt að heimilt sé að setja reglur, sem takmarka að einhverju leyti fjórfrelsið, til að ná fram pví markmiði að koma í veg fyrir ólögmæt undanskot frá skatti. Hér verða almennu skilyrðin sem áður er fjallað um að vera fyrir hendi. Reglurnar mega fela í sér beina mismun, brýnir almannahagsmunir verða að vera í húfi, líkur verða að vera á að reglurnar í raun nái markmiðum sínum og pær mega ekki ganga lengra en nauðsyn krefur til að ná peim markmiðum sem að er stefnt. Í pví sambandi verða reglurnar að beinast að tilteknum

54 Sjá t.d. Nikolaj Vinther og Jan Guldmand Hansen, „,EU-rettens krav til dansk skatteret,“ bls. 228. 55 Sjá m.a. grein 40 í máli C-319/02, Manninen og grein 14 í máli C-422/01, Skandia. 
tegundum ráðstafana og mega ekki vera of almennar. Раð verður með öðrum orðum að fara fram sjálfstæð athugun á pví hvort dregið hafi verið undan skatti. ${ }^{56}$ Á petta reyndi bæði í Lankhorst-Hohorst-málinu, C-324/00, og máli Lasteyrie du Saillant, C9/02. Í síðarnefnda málinu var skattur við brottflutning frá Frakklandi (exit skattur) til skoðunar. De Lasteyrie flutti frá Frakklandi til Belgíu í september 1998. Vegna flutningsins var lagður skattur á óinnleystan söluhagnað hlutabréfa sem hann átti í frönsku fyrirtæki en óumdeilt var að slík skattskylda hefði ekki stofnast hefði hann ekki flutt úr landi. Mögulegt var að fá skattlagningu frestað, og niðurfellda eftir 5 ár, með pví að leggja fram tryggingu fyrir reiknuðum skatti. Í málinu kom fram að tilefni pessarar löggjafar í Frakklandi voru mörg tilvik par sem skattgreiðendur höfðu flutt heimilisfesti sitt tímabundið til nágrannaríkja í peim tilgangi einum að komast hjá skattlagningu söluhagnaðar hlutabréfa. Dómstóll Evrópusambandsins taldi pessar skattareglur brjóta í bága við 43. gr. EB (nú 49. gr. ESB) par sem pær fólu augljóslega í sér skattalegt óhagræði fyrir pá sem vildu færa sig á milli landa. Dómstóllinn taldi að jafnvel pótt viðurkennt væri að ríkjum væri heimilt að grípa til aðgerða til að hindra undanskot frá sköttum, væru reglur af pessu tagi óheimilar. Pær bitnuðu á öllum sem vildu flytja frá Frakklandi og engin sérstök skoðun færi fram á pví hvort flutningurinn væri eiginlegar málamyndaráðstafanir í peim tilgangi að sniðganga skattareglur. ${ }^{57}$ Af pessum dómi má sjá að almennar reglur, sem auðveldlega geta hitt fyrir fleiri en pá sem reyna að sniðganga skattareglur, er erfitt að réttlæta með vísun til mikilvægra almannahagmuna.

Dómstóllinn gerir strangar kröfur til meðalhófs í úrræðum aðildarríkja gegn skattundanskotum og skattsvikum svo sem kemur fram í máli C-451/05, ELISA, sem varðaði löggjöf í Frakklandi um eignarskatta af fasteignum. Umdeildur skattur var lagður á félag í Lúxemborg sem stofnað var á grundvelli laga frá 1929. Félög pessarar tegundar eru undanpegin flestum tegundum skatta í Lúxemborg og um pau gilda reglur sem takmarka skyldu peirra til upplýsingagjafar til skattyfirvalda í Lúxemborg. Af peirri ástæðu var yfirvöldum í Lúxemborg hvorki heimilt né mögulegt að veita öðrum skattyfirvöldum upplýsingar um pessi félög. Tilskipun 77/799 um gagnkvæma aðstoð í skattamálum tekur samkvæmt efni sínu ekki til pessara félaga. Frönsk skattalög gerðu aftur á móti að skilyrði fyrir pví að erlend félög nytu sömu skattalegu meðferðar í Frakklandi og frönsk félög, að mögulegt væri að afla slíkra upplýsinga í gegnum samninga við viðkomandi ríki par sem félagið var heimilisfast. Rök franskra stjórnvalda voru pau að slíkar reglur væru nauðsynlegar til að koma í veg fyrir undanskot skatta og báru pví við að rökstuddur grunur væri um að aðilar skattskyldir í Frakklandi notuðu pessa tegund félaga til að komast undan lögboðnum skattgreiðslum. Dómstólinn féllst á að reglur væru nauðsynlegar til að koma í veg fyrir undanskot, p.e. að brýnir almannahagsmunir lægju peim að baki og taldi að reglurnar væru líklegar til að ná pví markmiði. Hins vegar taldi hann að útfærsla

56 Nikolaj Vinther og Jan Guldmand Hansen, „EU-rettens krav til dansk skatteret,“ bls. 228. 57 Grein 50. 
peirra í franskri skattalöggjöf gengi lengra en nauðsynlegt væri til að ná pví markmiði, par sem reglurnar útilokuðu fyrirfram öll tilvik par sem ekki væri hægt að afla fullnægjandi upplýsinga á grundvelli ofangreindrar tilskipunar eða tvíhliða samninga Frakklands við viðkomandi ríki. Taldi dómstóllinn að ná mætti sömu markmiðum með pví að heimila viðkomandi skattgreiðanda sjálfum að leggja fram pær upplýsingar sem nauðsynlegar væru til að koma í veg fyrir undanskot. ${ }^{58}$

Pað er aftur á móti ekki heimilt að setja reglur sem takmarka fjórfrelsið í peim tilgangi að koma í veg fyrir að skattaðili nýti sér hagstæðari skattareglur í öðru aðildarríki. Petta kemur víða fram í dómum Evrópudómstólsins, m.a. í máli C-9/02, Lasteyrie du Saillant og C-294/97, Eurowings. Í Cadbury Schweppes-málinu segir um petta atriði, par sem fyrir lá að yfirlýstur tilgangur með stofnun dótturfélaga í Alpjóðlegu fjármálapjónustumiðstöðinni í Dublin var að njóta hagfelldara skattaumhverfis sem par var boðið, að pað fæli í sjálfu sér ekki í sér misnotkun á fjórfrelsisreglum ESB. ${ }^{59}$

\subsection{Virkt skatteftirlit}

Skattyfirvöld hafa í ýmsum málum fyrir Evrópusambandsdómstólnum haldið pví fram að reglur, sem fela í sér takmarkanir á fjórfrelsinu, helgist af pörf fyrir skilvirkt skatteftirlit. Dómstóllinn hefur fallist á að brýnir almannahagsmunir felist í virku skatteftirliti sem geti af peim sökum réttlætt takmarkanir á fjórfrelsisákvæðum sáttmálans. ${ }^{60}$ Hins vegar gerir dómstóllinn strangar kröfur til pess að slíkar reglur gangi ekki lengra en nauðsyn krefur til að ná markmiðum sínum. Pannig taldi dómurinn í tilvitnuðu máli Futura Participations að skattalög í Lúxemborg settu of ströng skilyrði í skattalögum fyrir pví að taka til greina tap á móti hagnaði fyrirtækisins. Um var að ræða útibú fransks fyrirtækis en samkvæmt samningi ríkjanna tveggja var rétt og skylt að skattleggja tekjur útibúsins í Lúxemborg par sem tekjurnar voru upprunnar. Parlend skattalöggjöf gerði hins vegar ráð fyrir pví að tap undangenginna ára yrði einungis yfirfæranlegt milli ára, að sýnt væri fram á að fyrirtækið hefði haldið sjálfstætt bókhald fyrir útibúið í Lúxemborg á umræddu tímabili sem tæki mið af parlendum skattareglum. Í málinu var pví haldið fram að pessar reglur helguðust af pörf fyrir virkt skatteftirlit en dómstóllinn taldi pað ekki fá staðist, par sem bókhaldskrafan var bundin við heimild til að yfirfæra tap milli ára. Að öðru leyti voru útibú erlendra fyrirtækja ekki bókhaldsskyld par í landi. ${ }^{61}$

Pá hefur dómstóllinn ítrekað látið pað álit uppi að aðildarríkjum Evrópusambandsins kunni að vera heimilt að takmarka rétt til stofnsetningar fyrirtækja ef sýnt er fram á að slíkar reglur komi í veg fyrir hreinar málamyndaráðstafanir fyrirtækja í

58 Sjá grein 94 hvað síðasttalda atriðið varðar.

59 Grein 38. Á hinn bóginn kann að vera grönn lína milli pess sem dómurinn kallar notkun og misnotkun fjórfrelsisákvæðanna, sbr. t.d. mál C-212/97, Centros.

60 Sjá t.d. 31. grein í máli C-250/95, Futura Participations.

61 Sjá 37. grein dómsins. 
pví augnamiði að skjóta sér undan landslögum viðkomandi ríkis. Petta kemur m.a. fram í máli Cadbury Schweppes en í pví máli reyndi á breska CFC-löggjöf (reglur um pvingaða samsköttun). Deilt var um skattlagningu tveggja dótturfélaga Cadbury Schweppes, sem höfðu pann tilgang að veita móðurfélaginu ýmiss konar fjármálapjónustu. Fyrirtækin voru sett á fót í Alpjóðlegu fjármálapjónustumiðstöðinni í Dublin á Írlandi par sem skatthlutfall fyrirtækja var umtalsvert lægra en í Bretlandi á sama tíma. Í niðurstöðu dómsins er ekki kveðið upp úr um hvort umdeild löggjöf stangast á við staðfesturéttarákvæði ESB-sáttmálans en gefnar ítarlegar leiðbeiningar um pað út frá hvaða sjónarmiðum beri að meta lögmæti hennar. Kemur m.a. fram í dóminum að staðfesturéttarákvæðið komi í veg fyrir að ríki skattleggi tekjur dótturfélaga í öðrum ríkjum sambandsins, par sem skatthlutfall sé lægra, nema sýnt sé fram á að um hreina málamyndastarfsemi sé að ræða (e. wholly artificial arrangement) sem hafi pann eina tilgang að komast hjá skattlagningu í heimaríki móðurfélagsins. ${ }^{62} \mathrm{Af}$ pessum og fleiri dómum má ráđa að heimildum aðildarríkjanna til að grípa til aðgerða gegn pessari tegund skattasniðgöngumála er sniðinn pröngur stakkur. ${ }^{63}$

Loks skal nefnt að Evrópusambandsdómstóllinn hefur ekki fallist á takmarkanir á fjórfrelsinu á peim grundvelli að slíkt sé nauðsynlegt til að gera skattyfirvöldum kleift að afla upplýsinga um ætluð skattsvik eða undanskot. Dómstóllinn vísar til pess að aðildarríki geti notað reglur sambandsins um gagnkvæma aðstoð skattyfirvalda og á par við tilskipun ráðsins nr. 77/799/EEC eða eftir atvikum tvísköttunarsamninga milli ríkja. ${ }^{64}$ Tilskipun pessi gerir ráð fyrir pví að tilteknar upplýsingar fari sjálfkrafa með reglubundnum hætti, eða pegar sérstakt tilefni er til, á milli aðildarríkja og jafnframt að pau skiptist á upplýsingum pegar eftir pví er leitað. Tilskipun pessi er hins vegar ekki hluti EES-samningsins og pað virðist hafa ráðið úrslitum varðandi niðurstöðu í máli C-540/07, Framkvæmdastjórnin gegn Ítalíu. Par voru reglur um afdráttarskatt á arðgreiðslur til fyrirtækja utan Ítalíu taldar stangast á við grunnreglu bandalagsréttar um frjálsa fjármagnsflutninga par sem skatthlutfall arðgreiðslna til erlendra fyrirtækja var almennt hærra en hvað varðar greiðslur milli ítalskra fyrirtækja. Ítölskum stjórnvöldum stoðaði ekki að bera fyrir sig að reglurnar væru nauðsynlegar til að stemma stigu við skattaundanskotum og var m.a. bent á ofangreinda tilskipun til að afla upplýsinga um skattgreiðendur innan Evrópusambandsins. Hins vegar komst dómstóllinn að öndverðri niðurstöðu varðandi fyrirtæki í EFTA-ríkjum EES-svæðisins. Hvað pau varðar var niðurstaða dómsins sú að ríkir almannahagsmunir (overriding public interest) réttlættu takmarkanir á frjálsum fjármagnsflutningum skv. 40. gr. EES. ${ }^{65}$ Tók dómurinn fram að samvinna skattyfirvalda á grundvelli tilskipunar 77/799/EEC væri ekki fyrir hendi gagnvart EES-ríkjunum og virðist jafnframt byggja á peirri fullyrðingu ítalskra yfirvalda að ekki væru fyrir

62 Sjá 75. grein dómsins.

63 Sjá t.d. C-324/00, Lankhorst-Hohorst, C-9/02, Lasteyrie du Saillant og C-446/03, Marks \& Spencer. 64 Sjá t.d. 71. grein í C-196/04, Cadbury Schweppes.

65 Sjá greinar 67 og 68. 
hendi samningar um gagnkvæm upplýsingaskipti milli Ítalíu og viðkomandi ríkja. Раð rýrir hins vegar gildi dómsins að dómstóllinn virðist ekki hafa lagt sjálfstætt mat á raunverulega möguleika til aðstoðar og upplýsingaskipta milli Ítalíu og EESríkjanna á grundvelli gildandi samninga. Í tvísköttunarsamningi milli Íslands og Ítalíu, sem tók gildi í upphafi árs 2009, er t.d. ákvæði í 27. gr. um gagnkvæm skipti á upplýsingum milli skattyfirvalda sem takmarkast hvorki við pá aðila né pá skatta sem samningurinn tekur til.

Eftir stendur hins vegar að niðurstaðan er með skýrum hætti sú að almennu ákvæði EES-samningsins, sem eru samhljóða ákvæðum ESB-sáttmálans, eru túlkuð með mismunandi hætti á EES-svæðinu og innan Evrópusambandsins. Grundvöllur mismunandi túlkunar byggir á pví að tilskipun ESB sem ekki hefur gildi á EESsvæðinu pótt pau almennu ákvæði grundvallarsamninganna sem reynir á séu efnislega samhljóða. Pví er ljóst að pað parf í sérhverju tilviki að kanna hvaða áhrif afleidd löggjöf, eða jafnvel önnur ákvæði ESB-sáttmálans eða EES-samningsins, geta haft á túlkun meginreglnanna.

\section{Niðurlag}

Ólíkt flestum öðrum alpjóðasamningum er samningurinn um Evrópska efnahagssvæðið síkvikur. Hann tekur stöðugum breytingum bæði fyrir tilstuðlan formlegra breytinga og nýrra gerða sem tengjast honum en ekki síður vegna áhrifa Evrópudómstólsins og EFTA-dómstólsins við túlkun ákvæða hans. Evrópuréttur var til skamms tíma ekki talinn hafa mikil áhrif á sviði skattaréttar en reyndin hefur orðið önnur, fyrst og fremst vegna fjölgunar dóma á pví sviði par sem almennum leikreglum hins innri markaðar er beitt á skattalöggjöf aðildarríkjanna. Eitt meginmarkmið EES-samningsins er að koma á sameiginlegum innri markaði á EES-svæðinu og tryggja einsleitni reglna sem um hann gilda. Af peim sökum hafa úrlausnir Evrópudómstólsins varðandi túlkun grundvallarreglna sem snerta starfrækslu innri markaðarins mikla pýðingu við túlkun samhljóða ákvæða EES-samningsins.

Mikil fjölgun skattamála fyrir Evrópudómstólnum hefur varpað skýrara ljósi á afstöðu dómstólsins til pess hvernig skattareglur purfa að líta út til að teljast samræmast frelsisákvæðum sambandsréttar. Meginreglan er sú að skattalöggjöf má ekki fela í sér mismunun byggða á ríkisfangi eða skattalegu heimilisfesti. Nokkrar undantekningar pessarar meginreglu er að finna í meginmáli EES-samningsins sjálfs. Mikilvægari er pó ólögfest regla sem heimilar takmarkanir á fjórfrelsisákvæðum samningsins á grundvelli brýnna almannahagsmuna enda sé sjónarmiða um meðalhóf gætt við útfærslu og beitingu slíkra reglna. Af peim málum sem komið hafa til kasta Evrópudómstólsins og EFTA-dómstólsins má sjá að pörf skattkerfisins til að setja fjórfrelsinu skorður er rökstudd með nauðsyn pess að tryggja innra samræmi í skattkerfinu, hindra skattasniðgöngu eða halda uppi skilvirku skatteftirliti. Í fæstum tilvikum hafa dómstólarnir tekið undir sjónarmið skattyfirvalda. Oftast er sjónarmiðum 
peirra hafnað eða pví settar verulegar skorður hvernig útfæra má reglurnar, pótt fallist sé á að lögmæt sjónarmið liggi að baki peim.

Í höfuðdráttum gilda sömu reglur á EES-svæðinu og innan Evrópusambandsins par sem grundvallarreglur um bann við mismunun og takmörkun á fjórfrelsinu eru pær sömu. Hins vegar kunna önnur ákvæði sáttmála ESB og afleidd löggjöf á sviði skattaréttar, sem ekki hefur verið tekin upp í EES-samninginn, að hafa áhrif á túlkun meginreglnanna í tilteknum tilvikum. Í nýlegum dómi Evrópudómstólsins var niðurstaðan pannig sú að takmarkanir á frjálsum fjármagnsflutningum töldust réttlætanlegar á EES-svæðinu en ekki gagnvart fyrirtækjum innan Evrópusambandsins.

Pótt próun Evrópuréttar bendi til að æríkari kröfur séu gerðar til hlutleysis skattareglna gagnvart pjóðerni og staðsetningu pá eru pau skilaboð ekki alltaf skýr. Dómstóllinn virðist reyna að feta einstigið milli pess að krefjast jafnræðis og pess að viðurkenna svigrúm aðildarríkjanna til að ráđa sínum reglum sjálf. Petta tvennt fer ekki alltaf saman og pað fer ekki hjá pví að stundum eru röksemdir og niðurstöður dómsins misvísandi eða óljósar.

\section{Um höfundinn}

Ingibjörg Porsteinsdóttir er dósent við lagadeild Háskólans á Bifröst. Netfang: ingibjorg@bifrost.is. Greinin byggir að hluta á rannsókn um tengsl skattaréttar og EES-réttar sem unnin var árið 2007 með styrk frá Norræna skattrannsóknarráðinu. Vinnugrein um sama efni birtist sem „Skattaréttur og EES-samningurinn,“ Tímarit um félagsvísindi 1 (2007), bls. 72-95.

\section{Heimildaskrá}

Alpingistídindi.

Arnold, Brian J. og Michael J. McIntyre: International tax primer. Kluwer Law International. Haag 2002.

Baker, Philip: „Taxation and the European Convention on Human Rights.“ I British Tax Review 2000, bls. 211-377.

Blanchet, Thérèse, Risto Piipponen og Maria Westan-Clément: The agreement on the European Economic Area: a guide to the free movement of goods and competition rules. Clarendon Press. Oxford 1994.

Bullen, Andreas: EU, EØS og skatt: de fire friheter og direkte beskatning. Gyldendal Akademisk. Oslo 2005.

Commission of the European Communities: „A constitution for the Union." Commission Communication COM (2003) 548 final. Brussels, 17 september 2003. Slóð: http://eurlex.europa.eu/LexUriServ/LexUriServ.do?uri=COM:2003:0548:FIN:EN:PDF

Cordewener, Axel, Georg Kofler og Servaas Van Thiel: „The clash between European freedoms and national direct tax law: public interest defences available to the Member States." Common Market Law Review 46 (2009), bls. 1951-2000.

Dajani, Omar G., o.fl.: EØS-avtalen og norsk skatterett. Universitetsforlaget. Oslo 2003.

Davíð Pór Björgvinsson: EES-réttur og landsréttur. Codex. Reykjavík 2006. 
Hansen, Jan Guldmand, Nikolaj Vinther og Erik Werlauff: Sambeskatning 2006/07. Magnus Informatik. København 2006.

Organization for Economic Cooperation and Development. Model tax convention on income and on capital: condensed version. París 1998.

Jón Elvar Guðmundsson: „European tax law in the relations with the EFTA countries. “ I Intertax, 34 (2006), bls. 58-85.

Ingibjörg Porsteinsdóttir: „Evrópskur skattaréttur: átök og árangur á sviði skattaréttar Evrópusambandsins." Grábrók: tímarit lagadeildar Háskólans á Bifröst 1 (2009): 31-68.

Lang, Michael: „Direct taxation: is the ECJ heading in a new direction?“ European Taxation, september 2006, bls. 421-430.

Larking, Barry: „Fokus Bank: the end of withholding tax as we know it?“ EC Tax Review 14 (2005), nr. 2, bls. 69-77.

Lyal, Richard: „Non-discrimination and direct tax in Community law.“ EC Tax Review 12 (2003), nr. 2, bls. 68-74.

Ståhl, Kristina: „EU-samarbetets betydelse på den direkta beskattningens område gemenskapens kontra medlemsstaternas intressen. "I Í Forhandlingerne ved det 37. nordiske Juristmøde i Reykjavík 18.-20. august 2005, 1. bindi, bls. 383-396. Reykjavík 2005.

Stefán Már Stefánsson: Evrópusambandið og Evrópska efnahagssvæðið. Orator. Reykjavík 2000.

Stefán Már Stefánsson: „Leyfilegar takmarkanir á fjórfrelsisákvæðum EB/EES réttar. “ Í Rit lagadeildar Háskólans á Bifröst, bls. 411-428. Bifröst 2006.

Stokholm, Jeppe R.: EU skatteret. Thomson. Kaupmannahöfn 2008.

Sørensen, Karsten Engsig og Poul Runge Nielsen: EU-retten. 4. útgáfa. Jurist- og Økonomforbundets Forlag. Kaupmannahöfn 2008.

Terra, Ben J. M. og Peter J. Wattel: European tax law. 4. útgáfa. Kluwer. Haag 2005.

Vanistendael, Frans: „Denkavit Internationaal: the balance between fiscal sovereignty and the fundamental freedoms?" European Taxation, 2007, nr. 5, bls. 210-213.

Vinther, Nikolaj og Jan Guldmand Hansen: „EU-rettens krav til dansk skatteret.“ SR-Skat, 2004 (4), bls. 224.

Vinther, Nikolaj og Erik Werlauff: „Hvad bør Danmark gøre ved problemet „tynd kapitalisering" efter dommen in Lankhorst-Hohorst? Et utjenligt forsøg på at gøre dansk skatteret EU-konform." Skat Udland 2003, nr. 11, bls. 796-798.

Zimmer, Frederik: Internasjonal inntektsskatterett: en innføring. 3. útgáfa. Universitetsforlaget. Oslo 2003.

\section{Dómaskrá}

EFTA-dómstóllinn:

E-6/98, 20. maí 1999, Ríkisstjórn Noregs gegn ESA.

E-1/04, 23. nóvember 2005, Fokus bank ASA.

E-5/04, 21. júlí 2005, Fesil ASA og Finnfjord Smelteverk AS gegn ESA.

Evrópudómstóllinn:

C-270/83, Avoir-fiscal: Commission of the European Communities v French Republic. ECR (1986) bls. 00273. 
C-360/89, Framkvæmdastjórnin gegn Ítalíu: Commission of the European Communities v Italian Republic. ECR (1992) bls. I-03401.

C-195/90, Framkvæmdastjórnin gegn Pýskalandi: Commission of the European Communities v Federal Republic of Germany. ECR (1992) bls. I-03141.

C-204/90, Bachmann: Hanns-Martin Bachmann v Belgian State. ECR (1992) bls. I-00249.

C-330/91, Commerzbank: The Queen v Inland Revenue Commissioners, ex parte Commerzbank AG. ECR (1993) bls. I-04017.

C-279/93, Schumacker: Finanzamt Köln-Altstadt v. Roland Schumacker. ECR (1995) bls. I00225.

C-250/95, Futura Participations: Futura Participations SA and Singer v Administration des contributions. ECR (1997) bls. I-02471.

C-212/97, Centros: Centros Ltd v Erhvervs- og Selskabsstyrelsen. ECR (1999) bls. I-01459.

C-294/97, Eurowings: Eurowings Luftverkehrs AG v Finanzamt Dortmund-Unna. ECR (1999) bls. I-07447.

C-307/97, Saint-Gobain: Compagnie de Saint-Gobain, Zweigniederlassung Deutschland v Finanzamt Aachen-Innenstadt. ECR (1999) bls. I-06161.

C-311/97, Royal Bank of Scotland: Royal Bank of Scotland plc v Elliniko Dimosio (Greek State). ECR (1999) bls. I-02651.

C-324/00, Lankhorst-Hohorst: Lankhorst-Hohorst GmbH v Finanzamt Steinfurt. ECR (2002) bls. I-11779.

C-436/00, X\&Y: X and Y v Riksskatteverket. ECR (2002) bls. I-10829.

C-422/01, Skandia: Försäkringsaktiebolaget Skandia (publ) and Ola Ramstedt v Riksskatteverket. ECR (2003) bls. I-06817.

C-9/02, Lasteyrie du Saillant: Hughes de Lasteyrie du Saillant v Ministère de l'Économie, des Finances et de l'Industrie. ECR (2004) bls. I-02409.

C-319/02, Manninen: Petri Manninen. ECR (2004) bls. I-07477.

C-376/03, D: D. v Inspecteur van de Belastingdienst. ECR (2005) bls. I-05821.

C-446/03, Marks \& Spencer: Marks \& Spencer plc v David Halsey (Her Majesty's Inspector of Taxes). ECR (2005) bls. I-10837.

C-196/04, Cadbury Schweppes: Cadbury Schweppes plc and Cadbury Schweppes Overseas Ltd v Commissioners of Inland Revenue. ECR (2006) bls. I-07995.

C-374/04, ACT Group Litigation: Test Claimants in Class IV of the ACT Group Litigation v Commmissioners of Inland Revenue. ECR (2006) bls. I-11673.

C-170/05, Denkavit: Denkavit Internationaal BV and Denkavit France SARL v Ministre de l'Économie, des Finances et de l'Industrie. ECR (2006) bls. I-11949.

C-379/05, Amurta: Amurta SGPS v Inspecteur van de Belastingdienst/Amsterdam. ECR (2007) bls. I-09569.

C-451/05, ELISA: Européenne et Luxembourgeoise d'investissements SA (ELISA) v Directeur général des impôts and Ministère public. ECR (2007) bls. I-08251.

C-540/07, Framkvæmdastjórnin gegn Ítalíu: Commission of the European Communities v Italian Republic. ECR (2009) bls. I-10983.

Hæstaréttardómar:

Hrd. 1990.2, Ákæruvaldið gegn Guðmundi Breiðfjörð Ægissyni.

Hrd. 2003.2045, Íslenska ríkið gegn Herði Einarssyni. 